University of Louisville

ThinkIR: The University of Louisville's Institutional Repository

1937

\title{
A comparative study of the treatment of the American Revolution of 1776 in some secondary school history textbooks used currently in England and in the United States of America.
}

Louise Shelley Powell

University of Louisville

Follow this and additional works at: https://ir.library.louisville.edu/etd

Part of the Education Commons, and the United States History Commons

\section{Recommended Citation}

Powell, Louise Shelley, "A comparative study of the treatment of the American Revolution of 1776 in some secondary school history textbooks used currently in England and in the United States of America."

(1937). Electronic Theses and Dissertations. Paper 1853.

https://doi.org/10.18297/etd/1853

This Master's Thesis is brought to you for free and open access by ThinkIR: The University of Louisville's Institutional Repository. It has been accepted for inclusion in Electronic Theses and Dissertations by an authorized administrator of ThinkIR: The University of Louisville's Institutional Repository. This title appears here courtesy of the author, who has retained all other copyrights. For more information, please contact thinkir@louisville.edu. 


\title{
UNIVERSITY OF LOUISVILUE
}

A COMPARATIVE STUDY

OF

THE TREATMENT OF THE AMERICAN REVOLUTION OF 1776

IN SOME SECONDARY SCHOOL HISTORY TEXTBOOKS

USED CURRENTLY

IN ENGLAND AND IN THE UNITED STATES OF AMERICA

\author{
A Dissertation \\ Submitted to the Faculty \\ of the Graduate School of the University of Louisvilie \\ In Partial Fulfiliment of the \\ Requirements for the Degree \\ of Master of Arts \\ Department of Education \\ By \\ Loulse Shelley Powell \\ Year \\ 1937
}


Name of Student:

Title of Thesis: A Comparative Study of the Treatment of the American Revolution of 1776 in some secondary school his tory textbooks usied currently in England and in the United States of America.

Name of Director:

Approved by a reading committee composed of the following members:

Representative of the Department of English:

Date: 7eb.1938 


\section{AN ACKNOWLEDGMENT}

In writing this thesis, it was found necessary to ask the assistance of many people and organizations. The writer should like to take this means of thanking them. Especially does she thank President R.A. Kent and Dean J.J. Oppenheimer for their helpful criticism and Miss Virginia Winstanley for her cheerful library assistance. Among others, her sincere appreciation is due to Miss Anna Voegtle, Miss Josephine Taylor, the Librarians of the Public Libraries of Chlcago, Illinois, and of New Orleans, Loulsiana, the Librarians of the University of Chicago, the University of the City of New York, and the Librarian of Teachers' College, Columbia University, the Superintendents of the Public Schools of New York, Seattle, Los Angeles, and San Francisco, the Ilbrary of Congress, the Office of Education of the Department of the Interior, the Institute of International Education, the American University Union, Ginn and Company, and Harper and Brothers. Without the information, books, theses, and criticism furnished by all of the above, the writing of this thesis would not have been possible. The writer gratefully acknowledges her deep appreciation. 
A COMPARATIVE STUDY

$\mathrm{OF}$

THE TREATMENT OF TPHE AMERICAN REVOLUTION OF 1776

IN SOME SECONDARY SCHOOL HISTORY TEXTBOOKS

USED CURREN TLY

IN ENGLAND AND IN THE UNITED STATES OF AMERICA 
TABLE OF CONTENTS 
I Statement and Analys is of the Thes is........... I

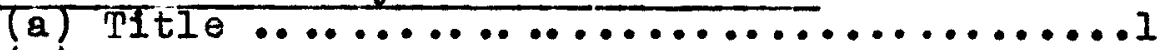

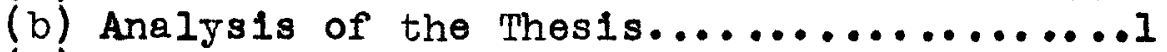

(c) Regulations Regarding the Adoption of

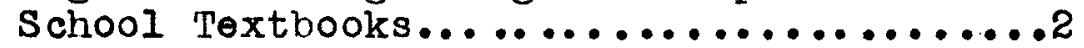

(d) Statutory Control of Textbooks...........4

(e) Importance of the Problem..............6

(f) Related Studies......................

(g) Criticism of the Related Studies.........16

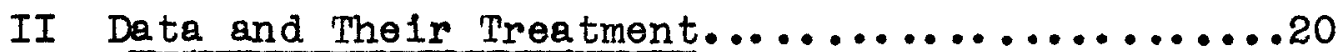

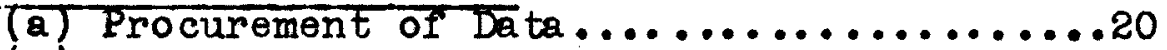

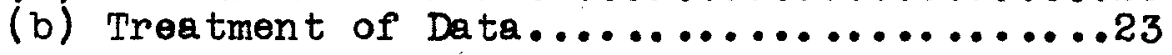

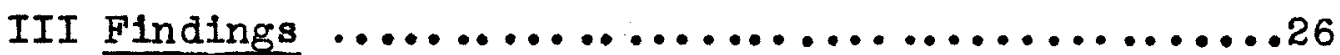

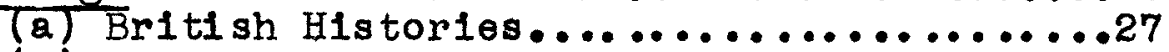

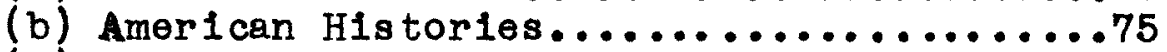

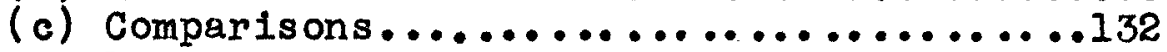

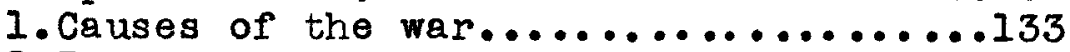

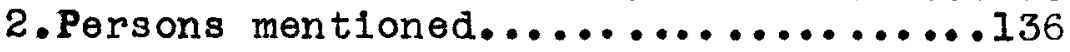

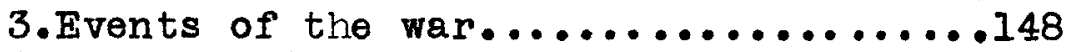

4. The most important event of the war...150

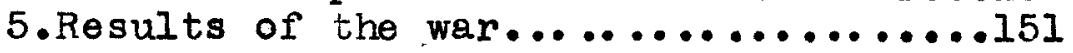

IV Summary and Conclusions..................153

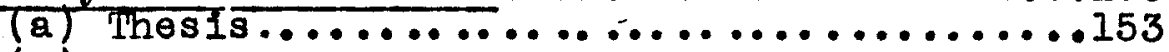

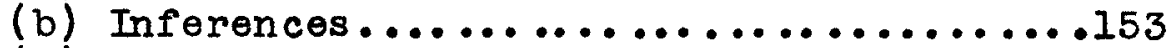

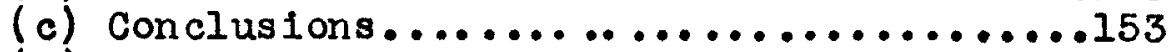

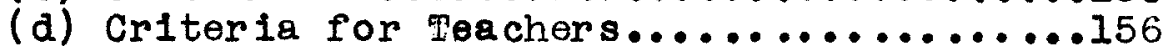

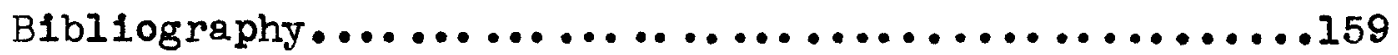


CHAPTIRR I

STATEMENT AND ANALYSIS OF THE THESIS 
CHAPTER I

STATEMENT AND ANALYSIS OF THE THESIS

Titie: a comparative study of the treatmont of the American Rovolution of 1776 in some socondary school history textbooks used currentiy in England and in the United States of America.

Analysis of the Thesis: Th1s study proposes to determine to what extent sinilarities and differences exist in the treatment of the American Rerolution of 1776 in some currently used history textbooks of the secondery schools of Fngland and of the Onfted States of America. To this ond five of the history textbooks used today in the secondary schools of England and five of those used today in the secondary schools of the United States of America will be examined. This number is, of course, only a sampling of the large number of history textbooks used in the secondary schools of the two countries. However the writer belleves that this number of books affords one a falrly accurate insight into the contents of all the history texts of the two countries as no effort was taken to gororn in anyway the history textbooks selected for examination. In examining the books the writer will take care to note 
anything which may prove a significant similarity or dissim1larity in their treatment of the American Rerolution of 1776. From the data thus collected, the writer will formwate her conclusions as to the extent to which similarities and dissimilarities exist in the history textbooks used today in the secondary schools of England and in those of the United States of America.

Regulations Regarding the Adoption of School Textbooks.

Ph1z1p Brand, in his Master's Thosis, A Comparatiro Study of the Treatment of the Causes of the Norld War in Secondary School Textbooks of Fingland, Germany, Neutral Powers and the United states, writton at the Colloge of the City of New York in 1935, makes the following statements regarding the regulations governing the adoption of school textbooks in Fngland and in tho United States of Anericas

\section{ENGIAND}

The cholce of books for use in the schools in Fingland rests with the $100 \mathrm{cl}$ education authorities, school governimg bodies and teachers. The Board of Education neither prescribes nor recommends particular books. A comon prectice of the local ducation authorities is to prepare $11 \mathrm{sts}$ of books which may be requisitioned for class use by the teachers in their schools. In the preparation of these lists, the advice of teachers and other competent persons is takon. 
THE DNITED STATES OF AMERICA

History textbooks used in the primary and secondary schools in the United States are published as commercial enterprises by about two dozen leading firins, some of which publish and circulate sereral texts by different authors. covoring the same ground and rulfilling the same noeds. The euthority to choose textbooks from this falriy centralized output is widely disseminated. In some of the fortyelght states, there is a state commission which passes upon all of the books to be used in the state. Ordinarily this censorship is negative, that is, it prohibits the use of certain texts but allows free cholce from a list of recommended books. In other states the cholce of books lies altogether with the local county, tornship or viliage oducation board. Frequently this board actualiy prescribes the sereral books to be used in each grado and subject, although in the remainder, the local school board exercises a permissive selection and the phoice is left to the school principal or teacher?

However Mr. Ward W. Keescker points out that in the United States:

Laws affecting the selection and use of textbooks are found in all states. These laws are of two general types: (I) Those providing for state selection and uniformity, and (2) those proriding for local selection and uniformity. Twentyfire states now hare laws providing for state selection and state-wide uniformity of textbooks. In some of these states exceptions are made for certain citles.?

1

Phil1p Brand, A Comparatire study of the Treatment of the Causes of the World War in Secondary School Textbooks of Ensland, cermany, Feutral powers and the united states. Masters Ihesis, College of the CIty of New York, 1935. pp.9-11.

2 nerd II. Keescker, Legislation Concerning Free Textbooks, Pamphlet No. 59. U.S. Department of the Interior, OfIIce of Fducation, Washington, U.S. Government Printing Office, 1835. p8. 
Mr. Brand also tates in his thesis the following regarding laws affecting the adoption of school textbooks In Fingland and in the Onited states:

STATUTORY FNACTMENTS AND OTHER FORCES

AFFECTING TEXTBOOKS

GREAT BRITATN

In Great Britain no specific action has been taken to purge textbooks which might create international bad foeling. The pollcy adopted is to oncourage the good rather than to condemn the bad. New textbooks might be submitted to a properly constituted board or comeltteo of historians for their approval; but probably a large majority of history teachers in English secondary schools rould prefer to continue to onjoy their present liberty of choice of books for their ow schools. They feel that they could themselves best discount the undue bias of the writer on any particular subject. The primary duty of the teacher is not so much to conrert his pupils to any particular point of view of intermational questions as to give them an opportunity of loarning the true facts for themselves and witimately forming sound judgments in the light of those facts. That a teacher's own interpretation of facts and events would be colored by his own bias is ineritable; but ho should always be on guard to prerent this tendency from becoming too paramount.

\section{THE UNITED STATES}

In 1918 Nen York approved another Lusk Law prohibiting the use of any textbook which contained statements of seditious character disloyal to the United states or farorable to the cause of any oneury country. The law created a cormission to 
which any person ight ke complaints against textbooks in history containing disloyal statements. In case the commission dis approved of the book after examination, the board of oducation must abandon the use of the book. It was further provided that any person or authority continuing to use a condemed book would be considered gullty of a misdemeanor.

During the World War, European history textbooks bore the brunt of the attack. Discussions tending to bestow praise upon the Central Powers, or in any way to disparage the institution or powers of the Allies, were deemed dis loyal to the cause in which the United States was engaged. Not only were history textbooks condemed, but also textbooks in forelgn languages, particularly in German. The James Harvey Robins on Historles were excluded from the schools of Des Molnes, Iowa, because of the statement regarding Germany made in these books. Among the objections raised against Robinson's Modieral and Modern Times were tho character 1 zation of the Gorman government, the fallure. to 1 ix the responsibility upon Germany for bringing about the World War, and the fallure to discuss the riolation of all lars of humanity as woll as of international law by Germany. Any book having a pro-German element was forbidden in most of the states. Frery syllabus made Germany the only country in the world that was prepared and anxious for war because of hor autocratic gororment, the character of the Kaiser, militarism and naralism, Germany's desire for world domination and the insidious inculcation of loyalty in the German peoples in the Prussian system of education.

In Decomber 1923, there was held a meoting of the Amer loan Historical Association concerning the censorship of histery textbooks. It passed the following resolution:

- Whereas the propaganda has met with sufficlent success to bring about not only acute controversy in many cities but also the passage of 
censorship laws in several states, therefore

'Be It resolved by the Ame rican Historical Association ...that genuineand intelligent patriot1sm, no 1088 than requirement of honesty and sound scholarship demand that textbook writers and teachers should strive to prosent a trutheul picture of past and present, ... that criticism of history textbooks should, therefore, be based not upon grounds of patriotism but only upon grounds of falthfulness to foct as determined by specialists or tested by consideration of the eridence;-nthat the cultivation of pupils of a scientific temper in hiatory and the related social sciences; of a spirit of inquiry and a willingness to face unpleasant facts are far more important objectires than the teaching of special interpretations of particular events; and that attempts, howerer well meant, to foster natlonal arrogance and boastrulness ans indiscriminate worship of national honor can only tend to promote a harmful psuedopatriotism and

'Be it further resolved, that the successful continuance of such an agitation must ineritably bring about a rulnous deterioration both of textbooks and of texching, since self-respecting scholars and teachers will certainly not stoop to the methods adrocated. 15

The Importance of the Problem

In this age of striving to outlaw war, to establish world perce, to strengthen the League of Nations and the World Court and in every possible way to bring about international good-F111, as well as in this age of rearmament, one noed scarcely argue the importance of what textbooks contain and of how the material is trented. No one will deny that everyone, and especially the impressionable adolescents in the secon-

Philip Brand, op. c1t., pp. 13- 
dary schools of a country, is influenced by that which he reads and hoars. As Bertrand Russoll puts it in his Why Men Flght:

The power of education in forming character and opinion is very great and very generally recognized. The genuine bellefs, though not usualiy the profess od precepts of parents and teachers are almost unconsclously acquired by most children;and even if they depart from them in later life, something of them remains dee ply implanted, ready to emerge in a time of stress or crisis.2

Related Studies

The Office of Education of the Depertment of the Interior at Washington, $D . C$, reports the three related studies which are summarized below. These throe Master's theses come from the College of the Clty of New York. They are:

(1) Brand, Philip -.. A comparative study of the treatment of the causes of the World War in secondery school textbooks of England, Germany, Neutral Powers and the Onited States. Master's Thesis, 1935.

(2) Gargle, Irma N. -.. A comparative study of the treatment of the War of 1812 in English and Amerlcan secondary school history textbooks. Master's Thesis, 1933 .

(3) Palewsky, Isidore -.. A comparative study of the treatment of the American Revolution and its causes in the history textbooks of the elomentary schools of England and the United States. Master's Thesis, 1931.

4 Bertrand Russell, Why Men Fight, N.Y., Century, 1916.P.154. 
A sumary of these theses follows:

Brand, Philip

A Comparative Study of the Treatment of the Causes of the World War in Secondary School Textbooks of England, Germany, Noutral Powers and the United States.

Scope of Study:

Trelve American, ten British, seven German, eleven noutrel [Firo Dan1sh, two Jutch, two Swodish, two Norwegian] textbooke were chosen in the light of their treatment of the causes of the World War.

Conclusions:

(1) A majority of the American books are pro-Alliod.

(2) Most of the British books are impartial.

(3) Erery German book is pro-Central.

(4) Most noutral books are pro-Allied.

(5) Only one neutral book is pro-Central.

(6) No Amer ican or British book is pro-Central.

(7) The American and British books are written with a feeling to give the facts as they occurred and to let the reader form his own conclusions.

(8) The German textbooks are written with a feolIng to show Germany entirely innocent of all censure that is heaped upon 1 . 
(9) In the Allied countries, the more recent the publicetion of a book, the more impartial it is.

(10)A Later edition of a German textbook shows Germany not at all culpablo.

(11) In general, there is a tendency in the Allied textbooks to speak of Russia's guilt as well as that of Germany.

(12) The German textbooks give themselres a "clean bill of health" and blame Russia for starting the war.

(13)Both the war-participants and the neutral powers treat the causes of the war as an important event in the history of the world.

(14)All books agree that the assassination of the Archduke was the Immediate cause of the war.

(15) Imperialism and militarism are most mentioned as the fundamental causes of the war.

(16) The Neutral textbooks give practically the same causes of the war while the belligerent authors differ considerably.

(17)All the textbooks with the exception of one German book agree that England tried to stop the war.

(18) The Neutral textbooks and even a few Gorman writers regard the ultimatum to serbia as too harsh and one that would have reduced that country into a mere rassal state. 
(19) The American authors feel (and so do a few British) that though England declared war on Germany because of the riolation of Belgian noutrality, jet the real cause was that Ingland feared a hostile nation ( and a very powerful one) in control of Belgium. (20) The German textbooks mention the invasion of Belgium in a factual way but give no apology.

(21) The Neutral countries, in general, mention the invasion of Belgium in pathotic terms.

(22) Ingland recelves the most unpopularity in German textbooks.

(23) The Germen books devote the greatest amount of space to the causes.

(24)Besides the Archduke Frances Ferdinand, Lord Groy is the most mentioned of personalities.

(25) In general, the English authors show the least disposition to hold England in any way accountable.

(26) In actual number of pages the American textbooks are most roluminous.

(27) The Neutral books devote the least amount of space to the ceuses of the war.

(28)Russian mobilization is the greatest factor in drawing all the nations of the world into the conflict. (29) Most textbooks seem to agreo with Fay and Langsam 
though the latter have had more access to the archires.

(30) The English authors consistently quote Grey, who in his memoirs writes "Fear was the cause of the War."

Gargle, Inge N.

A Comparative Study of the Treatment of the War of 1812

in Inglish and American Secondary School H1story Textbooks.

Scope of Study:

Ten American and ten British textbooks were chosen in the light of their treatment of the War of 1812 .

\section{Conclusions:}

(1) Most Amer 1can books are written to arouse a feeling of pride for the country.

(2)Most British books are not written to arouse a foelIng of pride for the country.

(3) Mmerican books treat of the War of 1812 as an important erent in the history of the United States.

(4)British books troat the War of 1812 an an incident in the history of Fingland.

(5) Most American books are prowAmerican. 
(6) Most Brit1sh books are pro-Brit1sh.

(7) Two American books present an impartial picture.

(8) Two British books present an Impartial picture.

(9) No Amer 1 can books are pro-British.

(10) One Brit1sh book is pro-American.

(11)All American books mention the Impressment of AmerIcan seamen' as a cause of the War.

(12) Most British books mention the Impressment of Amer1can seamen.

(13) Most American books emphasize Amerlcan victories and minimize British rictories.

(14)British books tend to minimize American victories and emphasize British rictories.

(15)Amer Ican books condider the Battle of Lake Erle as the most important battie on the sea.

(16)Few British books mention the Battle of Lake Erie. (17) To most Amer 1can authors, the burning of Washington, the Surrender at Detro1t, and the Battle of New Orleans are considered of greatest importance.

(18)Most British authors consider the burning of washIngton the most important event in the land warfare.

(19)American books mention more events than do British books.

(20)British books tend to give the more important and more significant erents. 
(21) American books mention 5.8 times as many American men as they do British men.

(22) British books mention 1.2 times as many British men as they do American men.

(23) Each American book gives at least one result.

(24) Some British books give no results.

(25) American books tond to give results that are of importance to Americe.

(26) British books tend to give results that are of Importance to Great Britain.

(27) The most important result of the war, according to the American books, is that the war completed the Independence of the United states. The result that is considered of most importance to Great Britain Is not mentioned by any American book.

(28) The result that is considered the most important by American authors is not mentioned by any British author.

(29) All the American books, but one, exceed the arerage percentage of the British books in regard to the total anount of space devoted to the war.

(30) $4 l$ the British books, but one, are belor the arerage of the American books in regard to the totel amount of space devoted to the war. 
Paiewsky, Isidore

A Comparative Study of the American Rerolution and

Its Causes in the History Textbooks of the Elomentary

Schools of Fingland and the United States.

Scope of Study:

Twentyeight textbooks -.. fourteen Finglish and fourteen American ... were analyzed in the light of their treatment of the American Rerolution of 1776.

Conclusions:

(1) The American books devote five times as much of the total spece to the treatment of the Rorolutionary War as do the British.

(2) In the American books, in general, the major portion of the treatment is deroted to the war proper.

(3) In the British books, in general, a minor part of the treatment is deroted to the war proper.

(4) No American book is actualiy anti-British.

(5) No American book is pro-British.

(6) Most American books are pro-American.

(7) No British book is ant1-American.

(8) Many British books are pro-American. 
(9) The American books, In general, devote a great deal of space to the figures involred. (Patriots,etc.)

(10) The Brit1sh textbooks, in general, do not mention more than nine or ten of the most prominent figures. (For example, Burke, Pitt, Wrshington, King George, Gates, Cormwallis, Howe).

(11) The smerican textbooks are written with a purpose of arousing in the ptipil a feeling of pride for his forbears, sympathy for their sufferings, and confidence in the ir righteousness.

(12) The British textbooks do not attempt to arouse a feoling of veneration for his forbears in the pupll.

(13) All the books fall to interpret the Revolution in Its brosdest significance.

(14) Sereral of the newest among the American textbooks attempt to put the causes of the war on a broader plane but they still retain the rest of the features of the other American history books. In other words they have added to the causes of the war, as usually found in the American textbook, those causes which are found in the modern higher historles which attempt to explain the Revolution on the lerel of a broad interpretation of fundamental questions. 
(15) In general, there is a tendency in the American books to give the British view but these never impugn the American view.

(16) The British textbooks often give the colonists' view of the question and in many cases, either justify tho colonists' action or conderm the 'unwise' enforcement by England.

\section{Crit1cism of the Foregoing Studies:}

The three studies sumarized above should prove most interesting to teachers of any subject in all countries. Most especially should they prove of interest to terchers of the social sciences in those countries whose textbooks the three thesis-writers analyze. Time spent in reading the conclusions of the three writers must of necessity cause one to pause and to consider how he can present an impartial picture of a debatable question regardless of the textbook he holds in his hand.

In handling the material, the three writers use the same method -.. they quote extensively from the various books in order to justify their eraluations of the books and to rerify their conclusions and comparisons.

All three thesis-writers find that the books of the rarious countries differ in thoir presentation of what 
1s presumably the same material. Bach textbook author tends to present the slant of his own particular country. In Miss Gargle's thesis, which compares the War of 1812 in Finglish and American secondary school textbooks, and in Mr. Paiewsky's thesis, which compares the American Rerolution in elementary school textbooks of England and the United states, a great similarity in their findings is obserred. The American books, they find, tend to derote more space to the subject matter then do the English books. The Amer lcan books mention more persons and erents and seem written to arouse pride in one's forbears. The English books mention few persons and events and tend to have no desire to asouse in the reader pride for his forbears. American books are inclined to be proAmerican whereas some of the British books are also inclined to be pro-American. The English books are found, on the whole, to present a more impartial picture of the various situations and to be falrer to both sides when presenting subject matter.

Mr. Brand, in his thesis regarding the causes of the World War as found in the textbooks of England, Germany, the United States, Norway, Sweden, Denmark and Holland finds that the textbooks of belligerent countries differ greatly as to what caused the World War but those of 
noutral countries give practically the same causes of the War. Among the textbooks used in the belligerent countries, for instance, one finds German textbooks frooing Germany of all blame for the war while Allied textbooks dirlde the blame between Germany and Russia. This difference of presentation of subject matter might cause one concern were it not for the hope presented by the newer textbooks in all countries. Both Mr. Brand and Mr. Palewsky point out that the nower textbooks tend to be more impartial and endeavor to present causes of the wars on a broad plane. The chler ralue of these studies $110 \mathrm{~s}$ in the fact that they clearly point to all teachers the nocessity of being broad-minded. If students are to be made world-minded in this age, when the world is clamoring for peace and yet preparing for war, they must be aldod in seeling all subjects from the riempoint not only of their own country but also from the viewpoints of other countries. Might this not suggest the wisdom of terching from the textbook in use in one's own country or clty and also of using as reference books the textbooks of other countries which deem the subject matter of sufficient importance to include it in their textbooks? In this way, one would have at least lain all the avail- 
able facts before his pupils and could then help them draw their own conclusions. In this wey, too, a better understanding of the other side of the argument might be attained.

A further study, along these lines, which might prove interesting, would be an investigation into the teaching methods of Social studies' teachers in different countries. What are the teachers of the Social sciences doing in their teaching, either with the textbook placed in their hands or in spite of it, to promote international understanding and good-w111? One wonders. 
CHAPTER II

DATA AND THEIR TREATMENT 
CHAPTER II

DATA AND THEIR TREATMENT

Procurement of Data: In order to ascertain with surety what were the titles of five of the history textbooks used today in the secondary sohols of England, the author wrote to the Institute of Intermational Education in Ner York C1ty. They did not have the arallable information but were helpful in suggesting that a lotter to their London office, The American Unirersity Union, night prove fruitful. This letter was duly dispetched. An answer listed the following fire books as among those now (August 28, 1936) used In the secondary schools of Ingland in the teaching of his tory 8

(1) Mowat, R.B. ---A Now History of Groat Britain Oxford University Press, London, 1923.

(2) Muir, Ramsey---British History,

G. Ph1lip and Son, London, 1930.

(3) Rayner, Robert M.... A Concise History of Brite in Longmans, Green and Co., London 1937.

(4) Somerrell, D.S. - - A Concise History of Great Britein, G. Bell and Sons, London, 1934. 
(5) Warner and Marten -.. The Groundwork of Br1t1sh History, Blackie and Son, London, 1923.

The Director of the American Unirersity Union, London Fngland, stated the following in his letter:

I am glad to append the 11st, which you desire, of five textbooks now [August 28, 1936] being used in the secondary schools of this country in the teaching of history..... I am af raid I am unable to tell you in which cities these history texts are used. Terchers in the schools of Ingland are quite freo to choose their own textbooks under the direction of the local authority directly responsible for their schools. This means that in practico there is a good deal of raplation in the cholce of textbooks used.

For the United States history textbooks used currentIf In the secondary schools of the United States of Amer1ca, it was decided to employ those in use in c1ties geographically located in the Rastern, Nestem, Northorn and Southerm parts. of the country. For th1s purpose, outstanding cities in these sections were chosen:

Bast --Now York C1ty, New York

West ---San Francisco, Callfornia

North --Chlcago, Illinois

South - New Orleans, Louislana

Letters were sent to elther the superintendents of the public schools in these cities or to the Librarians 
of their Free Public Iibraries. These letters asked for the name of the United Stetes history textbook used in the secondary schools of the city addressed. For the fifth United States of America history Textbook -.. to balance the fifth history textbook of Fingland -.. it was declded to use that of the secondary schools of Loulsrille, Kentucky, where the writer is a teacher. The list of the five United States history textbooks in use in the secondary schools in the onited States of Americe and secured in this manner are:

(1) Now York C1ty, N.Y. -.- Fite, Imerson Darld History of the United States, Henry Holt and Co., N.Y., 1916.

(2) San Francisco, Cal. -.. Muzzey, David Sevilie History of the American People, Ginn and Co., Boston, 1929.

(3) Chicego, Ill.-.Faulkner and Kepner America: Its H1story and People, Harper and Brothers, N.Y., 1934.

(4) New Orleans, La. --Muzzey, David Saville

History of the American People, Ginn and Co., Boston, 1929.

(5) Louisville, Ky.-.- Barker --Dodd -- Comager Our Nation's Derelopment, Row, Peterson and CO., N.Y., 1934. 
Since San Francisco, California, and New Orleans, Louisiana, reported the use of the same history textbook in their secondary 8 chools, It was decided to use the book once and to subst1tute for its second use any of the books listed as used in the teaching of history in the secondary schools of oither Now York or Chicago. As Beard and Beard's History of the United States was found on both of these lists, it has been used in this study to take care of the duplication of Muzey's History of the Amerlcan People. The complete information regarding this substituted book is :

Beard, Charles A. and Beard, Mary R. History of the United States, Mackilian Co., N.Y., 1929.

Treatment of the Data:

First, the American Rerolution of 1776 was reriewed in each book separately. Anj word or phrase which might in some way Indicate the aim of the book's author was looked for carefully. Passages which seomed to indlcate the character of the book were quoted. Then the writer made her own evaluation of the book. In eraluating the textbooks the following criterie were set up:

(1) Doos the author simply state the facts or does he color thom with his own opinions and rocabulary? 
(2) Does the author give one side only of the argument or does he state both sides?

(3) Is the blame for causing the war la1d on e1ther belligerent?

(4) Are excuses given for Ingland's fallure to win the war?

(5) Do the authors of the English textbooks speak with respect or in a derogatory manner of the smerican participants in the American Revolution?

(6) Do the authors of the American textbooks speak with respect or in a derogatory manner of the English participants in the American Revolution?

(7) Do the authors of the English textbooks pay any tributes to the Americans involved in the war?

(8) Do the authors of the American textbooks pay any tributes to the Inglishmen involved in the war?

(9) Do the books contain any statements which tend to promote good or bad will for elther country?

After the American Revolution of 1776 had been reviewed In a book as a unit, the writer next listed the causes of the war mentioned in the book, and also the persons, events, and results given. What the author considered as the most important ovent of the war was noted. The approximate number of words devoted to the American Revolution as well as the percentage of the book given to this subject were noted. 
The 1llustrations, maps and graphs, print and arrangement of the book to invite interest were observed.

When the above information had been carefully tabula te $d$ for each of the ten history textbooks, comparisons were made between the American and British books to seo wherein they were alike and unlike. Inferences and conclusions were then drawn. 
CHAPTER III

FINDINGS 


\section{CHAPTER III}

\section{FINDINGS}

Findings: In this chapter the writer will examine the fivo histories used in the secondary schools of England and the fire used in the secondary schools of the United States. In this examination the writer will limit herself to that portion of each book which treats the American Rerolution. She will quote those passages which tend to show the riewpoint of the authors or which seom to indicate the character of the books. She will gire her own eraluation based on the criter la set up in the procoding chepter. The causes of the war, persons mentioned, events, the most important event, and results will be listed. The amount of the total book's space given to the American Rerolution, the approximate number of words used, the number of 1llustrations, maps and graphs and the arrangement of the book for pup1l appeal will be noted. Nfter the ten books hare been examined in this manner, comparisons will be made and conclusions dram. 
BRITISH HISTORIFS

I- The Oroundwork of British History -- by

George Tormsend Marner and C.H.K. Marten

Blackle and Son, London, 1923.

The authors state the following about the American

Revolution of 1776 :

Condition of Fngland after the Seren Yoars' War

The Seven Years' War had left Great Britain triumphant.She had then, howerer, to organize hor ompire. But at th is most critical period, the king on the arlstocre oy which governed Great Brita in were unsympathet1c, and above al7, 1gnorant. The ministers were constantly changing and had no settled convictions; and later, Lord North's ministry though more stable -.-1t lasted from 1769 to 1782 -.. was also more incompetont. Above all, there was no great staterman capable of dealing with the situation, except parhaps William Pitt, who was too ill to make more than fitful appearances, and Edmund Burke, who never held high offico. And so Great Britain went blundering forward, and lost the larger part of her empire in the West whilst she with difflculty hold her own in the Bast. Leaming by experience is proverbially costly, but our statesmen mo do cost in these twenty years unnecessarily h1gh. (p.499).

Influence of Seren Years' $\operatorname{mar}$ on the Amer Ican Colonies

The conquest of Caneda freed the American colonies from danger of absorption by the French; and by so doing, onabled them to become independent of the mother country. Above all, the great expenses that foll, as a consequence of the war, upon the mother country led to an attempt to tax the colonies, 
which caused both the Puritan democrats of the North and the Anglican aristocratic and slave-owning planters of the South to unite for the first time in a common opposition. (pp.499-500).

Trade Restrictions

Up till the end of the Seven Years' War, no other colonies in the world had been 80 well treated as those in British America. In matters of government the colonies had no great grievances... In matters of trade, Great Britain no doubt regarded her colonies as a source of wealth. Consequently some of the chief colonial products, such as tobacco and cotton, could be exported only to Great Britain. The manufacture in America of steel or woollon goods, or even of hats, was IImited or forbldden, so as not to compete with British imports. All goods from Europe had first to be landed in Great Britain, and the colonies were also subject to the Narigation Act. No one now denles that these restrictions were unwise; but it must be remembered that Great Britain orred in company with all other mother countries-only to a less degree. (p.500).

\section{Grenvilie's Policy}

Grenvill $\theta$ decided that it was nocessary for the defence of the American colonies,... to keep a small standing army in America. He was probably right in this decision. Grenvilie was not unreasonable in thinking that the colonies themselves should contribute something toward their defence..... Nor was Grenvilie's particular proposal unreason$a b l e$. He suggested that the colonies should pay one-third of the expense of this army by means of an Act under which all legal documents should bear stamps. Moreover, he put forward this proposal in a very tentative and moderato way.... Legally the British Parliament had undoubtedly the right to pass the Stamp Act.....But, it was natural that a liberty-loring people should object to being 
taxed a Parliament in which they were unrepresentated. (pp.500-501).

The Colonists Irritate the Mother Country

The character of the colonists in the North ...was, In P1tt's phrase, 'umbrageous' (1.0. they took umbrage oasily) and quarrelsome, and their conduct was sometimes very irritating to the mother country. (p.502).

Tax on Toa Is Retained

But, with incredible folly, the duty on tea was retained, in orderto assert the right of taxing. (p.503).

The Real Difficulty

'The real difficulty,' it has been well said,

'was that Great Britain would not consent to a partnership, which was the only solution, but insisted upon dependency. The American colonles, therefore, hardened the ir hearts, and would accept nothing short of independence.' (p.504).

Why the British Lost the War

But the British made the mistake-mot unusual with them--of underestimating their enemy,... moreover, they made inadequate preparations for the dispatch of reinforcements to the army in America when they saw that war was probable.... The British also, not only falled to produce a great general, and fought largely with hired German troops, but possessed in Lord George Germaine... m minister of war who was to exhibit consplcuous incapacity. The colonists, on the other hand, had in a virginia planter, George Washington by name, $a$ man as Commander-in-chief who, without being perhaps a great general, was a thorough gentleman, upright and truthful, untiring in organization, and persistently courageous and steadfast even in the darkest perlods of the war. (p.506). 
The British Fall To Grasp Opportunities

During the first three years of the war (1775-7)

the British miesed their opportunities. (p.506).

Fingland Lacks A Groat Man.

During the next three years (1778-80), our onemies gradurily increased, and the sphere of our military operations was correspondingly extended.....But, unfortunately, Cha tham, who might have conducted such a war on sound princ1ples, died in 1778, and from the other pol1ticlans of the porlod it was hopeless to expect great or consistent designs. (p.509).

Great Britain Loses Control of the See

Great Britain no longer held command of the sea, and the French fleet was to form a declaive factor. (p.509).

Eraluation:

The authors endeavor to excuse Great Britain for all the mistakes made in the war. Such expressions as "the king and the aristocracy...mere unsympathet1c, and above all 1gmorant," "Lord North's ministry, though more stable, was also more incompetent," "Great Britain went blundering forward," are all excuses for lacking men capable of handling the situation. They oven go further in acknowledgIng they had no leader to compare with George Washington, who was perhaps "not a great general." Then Grenvillo's plan far Amer ican defence was "probably right" and "not unreas onable."

The colonists were assured a victory because Brita in "underestimated" the power of the enemy, made "In- 
adequate proparations" and had to wage war many miles from home when now enemies were springing up at home.

"Great Brita in would not consent to a partnersh1p, which was the only solution, but insisted upon a dependency" and"no one now denies that these restrictions of trade and manufacturing were unise" seem to be an honest effort on the part of the authors to show that Great Britain erred. But back of this lurks the excuse--she had no great man at this period of her history and her error was not nearly as great as those made by other mother wountries.

One might sum up the attitude of the authors by saying that they mo no effort to place the blame for the war on the Americen colonies. They do strive to excuse Great Britain's mistakes which were responsible for the war while also strive to excuse Great Britain for losing the war. 
Causes of the Nar as Related by the Authors:

(1) Trade restrictions

(2) Manufacturing restictions

(3) Narigation Acts

(4) Suppression of smuggling

(5) Establishment of a standing army in America

(6) Stamp Act

(7) Townshend Acts

(8) Boston Massacre

(9) Boston Tea Party

(10) Burning of a ship of the king

(12)closing of the port of Boston

(12) Suspension of the constitution of Massachusetts (13) Quebec Act

(14) Taxation without representation

Persons Discussed by the Authors:

Brit1sh

(1) Lord North

(2) William P1tt

(3) Edmund Burke

(4) The king -. George III

(5) Goorge Grenville

(6) Charles Townshend

(7) General Gage
(8) Lord Germaine

(9) General Carleton

(10) Sir William Howe

(II) John Burgoyne

(12) Sir Henry Clinton

(13)Lord Cornwallis

(14)Lord Rockingham 


\section{Amorican}

(1) George Washington

(2) Horatio Gates

(3) Nathaniel Greene

Events Commented upon by the Authors:

(I) Battle of Lexington

(2) Battle of Bunker's Hill

(3) Attack on Canada

(4) Eracuation of Boston by the British

(5) Battle of Long Island at Brooklyn

(6) Occupation of New York

(7) Occupation of Philadelphia by the British

(8) Battle of Trenton

(9) Battle of Saratoga

(10)Battle of Brandywine

(i7) Capture of Charleston, S.C.,by the British

(12) Capture of Btrannah, Ga., by the Brit1sh

(13) Eracuation of Philadophia by the British

(14)Battle at Camden

(15)Battle at Guildford Court House

(16) Surrender at Yorktow

The Most Important Event of the War in the Opinion of the Authors:

(1) Battle of Saratoga 
Results of the War as Noted by the Authors:

(1) Great Britain "1s deprived of one empire."

(2) The foundations of another empire (Canada) are streng thened.

(3) The Independence of the United States is recognized by Great Britain.

(4) Spain recelves Florida.

(5) France recolves sereral small 1slands.

Warmer and Marten's The Groundwork of British History deroted approximately 4,548 words to the American Revolut1on of 1776. Th1s covers about 1.7\% of the total space allotted to the book. The book contains no plctures or graphs and there is only one black and white map in the section deroted to the American Rerolution. The type is rather small and there seems to be no attempt to appeal to the interest through the organization of the book. 
II- A New History of Great Brita in -- R.B. Mowat

Oxford University Press, London, 1923.

About the American Revolution of $1776 \mathrm{Mr}$. Mowet

says the following:

George III Caused the American Revolution

George's personal intervention helped to produce the American Rerolution. (p.510).

Colonies Gorern Themselves

The colonies enfoyed a large amount of self-government. (p.517).

Cause of the Friotion

Commercial restrictions, wherever they exist, are always a great cause of friction. (p.518).

Passage of the Stamp Act

In 1765, however, under the premlershlp of George Grenvillo -.-an industrious and eff1cient minister, but not a statesman of wide outlook -.-a stamp Act was passed. (pp.518-19).

Taxation Without Representation

The colonists, on the other hand, denied that they could be taxed directly by a Parliament, sitting thousands of miles away, in wh1ch they had no representation. (p.519).

Burke's V1ew of the Stamp Act

The true view was express ed by Burke in one of his great speeches on conciliation. 'The Stamp Aet,' he sald,' could not be called 1llegal, though direct taxation of the colonles by Parliament was against constitutional custom. But if not 1llegal, the decision to impose direct taxation was unwise, and the amount of money to be got in comparison with the loyel colonies to be lost, not worth bothering about. (p.519). 
George III Belleves in the Old Colonial System

George believed that he must carry on the 0ld Colonial system as he had inherited it; the claim of the colonists to settle their om direct taxes meant a self-goverming empire of a completely new kind.' It would be better', wrote George to Lord North, 'to give up the empire than to admit one particle of these principles. (p.520).

Why Fingland Was Dofeatea

Broadly considered, however, the defeat of the Nother Country may be said to have been due to three things: to mismanagement at home, to the distance across the Atlantic, and to the rast and roadless spaces of the Colonies. (p.521).

One Cause of British Defeat

The administration at home was bad.George III's absorption in internal politics, the ondiess party intrigues, had withdram attention from tho Navy md Army. (p.52I).

Characterization of Lord Germaine

Lord Goorge Gernginewas able but unconscientious, and is sald not to have troubled even to read the colonial and military dispatches. (p.521).

The French Fleet Alds the Americans

Onfortunately; the naval policy of the time was not good.... The French fleet was allowed to sail in colonial wators and in 1781 it obtained (for a short time) sufficient command of the sea to bring about the capituIntion of General Iord Cormwalis in Yorktorn -n the decisire aetion of the war. (p.522).

Crit1cism of British Commanders

The British commanders showed extraordinary slowness in following up the rictories which 
they secured at the beginning of the war. (p.522). Another Reason for Fngland's Defeat

Britain, Assailed on the sea, in America, in India, found the strain too much. She could only deal effectively with one assailant at a time; and so with the intervention of France, the reconquest of the revolting colonies became almost imposs 1ble. (pp.525-26).

Commallis Makes a Mistake

He [Comwallis] allowed himself to commit a great strateglcal mistake by taking up what ho must have known to be a dangerous position in Yorktown. (p.526).

A Description of the Surrender at Yorktown

The author quotes from Mahon's History of Fngland a description of the surrender at Yorktown. Ho seys:' The two ines of the Allied arm, says Abbe Robln, 'were drawn out for upwards of a mile; the mericans haring the right. The disproportion of hoights and ages in their men, and their solled and ragged elothing might bo unfavorably contrasted with the neater and more soldierly appearance of the French. Yot, under such circumstances the personal disadrantages of a rall militia should rather bo looked upon as an enhancement of the triumph they had gained. The Abbe was truck at soeing, from sereral indicatiens, how much keoner was at that timo the animosity between the Figlish and the Americans than between the English and the French.1 (p.527).

Why Cornwallis surrendered

It was the temporary loss of the command of the sea by the British Nary that caused the fall of Yorktown, the final dieaster of the Amer Ican War. (p.527). 
The French Fleet Causes England's Defert

The Americans, under the able Soott1sh sailor, Paul Jones, began the fine traditions of the Onited States Nary; but it was the advent of the French fleot on the Amer 1can side which, for a short time, turned the scale against the British. (p.527).

The British Nary Loses Control of the Sea

For a fer wooks the British Nary did not command the sea, and this was the reas on why Yorktown could not be relleved and why Cornwallis had to surrender with his brave men to washington. (p.528).

Eraluation:

Mr. Howat presents a very unbiased ploture of the American Revolution of 1776. He shows that Great Britain made many mistakes and that sho precipitated the war. But he states that "the colonies enfoyed a large amount of self-government." He claims that it was the commercial restrictions and taxation without representation which Great Britain imposed on the colonies that brought about the final break between the mother country and her colonies. He quotes Fdmund Burke extensively ---quoting such statements as "the decision to impose taxation was unwise and the amount of money to be got in comparison with the loyal colonies to be lost, not worth bothering about." In his opinion the king and his statesmen were at fault. He says," George belleved that he 
must carry on the old Colonial system as he had inherited 1t; the claim of the colonists to settle their own direct taxes meant a self-governing empire of a completely new kind. 'It would be better,' wrote George to Lord North, 'to give up the empire than to admit one particle of these principles."

The 10se of the war by Great Britain is excused by such expressions as "Lord George Germaine was able but unconsclentious," "unfortunately the naval pollcy of the time was not good," "the British commanders showed extraordinary slowness in following up the victorles which they secured at the beginning of the war." Each of these is an excuse advanced in behalf of Great Bittain.

The author pays tribute to the American colonists by saying, "The American army was an untrained militia; but under Washington 1t gradually acquired discipline, and showed itself skilleul in 'regular' operations as well as in more irregular style of fighting which sulted the trackless nature of much of the country.

But he points out that the real cause of the loss of the war by Great Britain was the aid which the colonists recelred from the French fleot. He states that "It was the temporry loss of the command of the sea by the British navy that caused the fall of Yorktown, 
40

the final disaster of the American War."

He takes pains to mention with respect the beginning

of the United States Nary when he states,"The Americans, under the able scottish sailor, Paul Jones, began the fine traditions of the United States Nary."

Taken all in all, Mr. Marat's A Now History of

Great Britain presents a very unbiased story of the American Revolution of 1776. 
Causes of the War Menti oned in the Text:

(1) Narigation Acts

(2) Uanufacturing restrictions

(3) Taxation without representation

(4) Stamp Act

(5) Boston Massacro

(6) Burning of the Gaspee

(7) Boston Tea Party

(8) Closing of the port of Boston

(9) Suspension of the charter of Massachusetts

Persons Mentioned by the Author:

British

(1) Goorge III

(2) William Pitt

(3) Bolingbroke

(4) Lord Bute

(5) George Grenville

(6) Edmund Burise

(7) Lord Rockingham

(8) Duke of Grafton

(9) Lord North
(10) General Clinton

(II) Lord Commallis

(12) Admiral Howe

(13) Lord Germaine

(14) John Burgoyne

(15) Sir Carleton

(16) Lord Rawdon

(17) Admiral Rodney

\section{Amer1cans and Amer 1can Allies}

(1) Goorge Washington

(2) General Montgomery

(3) Benodict Amold

(4) General Schuyler
(5) Paul Jones

(6) Marquis de Lafayette

(7) Count Rochamberu

(8) Comte de Grasse 
Erents Mentioned by the Author:

(1) Battle of Lexington

(2) Battle of Bunker Hill

(3) American Invasion of Canada

(4) Battle of Brooklyn Helghts

(5) Capture of Philadelphia by the British

(6) Battle of Trenton

(7) Battle of Saratoga

(8) Capture of Charleston, S.C.

(9) Battle of Camden

(10)Battle of Guildford Court House

(II) Surrender at Yorktown

The Most Important Event of the Mar in the Opinion of the Author:

(1) Battle of Saratoga Results of the War Iisted by the Author:

(1) Full and complete Independence for the United states.

(2) A new type of empire was developed, the modern self-governing British Emplre.

(3) Great Britain ceded some small 1slands to France.

(4) Spain secured Florida.

R.B. Mowat's A New History of Great Britain derotes about 7590 words to a discussion of the Americen Revolut1on of 1776. This covers about $2.4 \%$ of the entire book. 
There are fire 1llustrations, one map and no graphs in that part given to the American Revolution. The print is small and the map and pictures are in black and white and no attempt to appoal to the student's interest through book arrangement has been made. 
III- British History -.- by Ramsay Muir

Q.Philip and Son, London, 1930.

The following passages are quoted from Mr. Mule's

British History:

Now Problems

The thirteon colonies were growing up, and the old colonial system, under which they had lired since 1660 , was manifestly working badly. (p.398).

Polit1cal Troubles in England

Parliament and the politicians could not give thoir minds to the greater questions of imperlal policy, because they were engrossed by the struggle between the king and the whigs. (p.398)

Characterization of Grenvilie

Grenvilie was an Industrious and thoughtful politician who had a great deal of knowledge about Amerlcan affalrs, and he did h1s best to deal fairly with the very difficult questions which the war [Seven Years' War] had ralsed. (p.400).

\section{Grenvilie Tries to Regulate American Trade}

He [Grenvilie] had found that the dues on colonial trade (which the colonists recognized as valid) were in fact evaded on a wholosale scalo, so that they ylelded scarcely any revenue. His general idea was to reduce them and make them reas onable, but at the same time to see that they were collected. (p.401).

Tho Should Pay for the British Army in America?

And as the colonists refused to maintain any forces of their own, a small British army had to be maintained for their protection. It seomed fair that they should contribute towards the cost of this. (p.40I). 
Reception of the Stamp Act

The passage of the Stamp Act produced an imediate upherval in the colonies. It was proclaimed to a denial of the principle of ino taxation without representation.'... In Fingland, Pitt supported the view of the colonists,asserting that they would be slaves if thoy paid taxes about which they had not been consurted. (p.402).

Reper I of the Stamp Act

The Rockingham ministry, which lestod only a year, was a foeble and ineffoctual gorornment..... It achleved only one measure of 1 inportance. It repealed the stamp Act (1766), and the clamour died down. But it accompanied the repeal with a Declaratory Act asserting the right of taxation. To assert a right without ondearoring to enforce it was mere folly, especially as it was the claim of a right to tax, rather than the actual burden, which the colonists resented. (p.402-3).

The Townshend Act

The Act [Townshend Act] stated that the purpose of the duties was to ralse revenues; and 1t was precisely the claim of a right to ralse revenue to which the colonists objected. (p.404).

The Duty on Tea 1s Reta ined

It was evident that the taxes could not be enforced. In March 1770, the Gorermment decided to w1thdraw them; but in order to maintein the principle, the duty on toa was preserved, though only by a majorlty of one-... so deoply divided was the cabinet. (p.405).

Attitude of Fingland toward Qoorge III's Policy

In reality the polley of George III' was not unpopular. The bulk of opinion, both in Parliament and in the country, supported h1s Amerloan pollcy, and thought that the colonists were unreasonable. (p.406). 
Englishmen Think The Colonists Unreas onable

The Massachusetts Assembly bocame practically a rebel government.General Gage began to fortify Boston against possible attack by the 'rebelsl... Most Engl I shmen thought it unreasonable that the colonists should expect to onjoy all the advantages of naval and milltary protection at the expense of the mother country, while refusing to contribute to the cost.Most of the colonists wore convinced that the essentials of selfgovernment were being challenged. (pp.407-8).

\section{Conciliation Impossible}

Chatham, in conjunction with Ben famin Franklin (who was living in England as an agent for some of the colonies) tried to devise a scheme of conciliation (1774), but tempers were too high to give it a chance. (p.408).

Who Is To Blame for the American Revolution?

The blame for this disaster, [the American Revolution], which was to lead, after a war of seven years, to the severance of the thirteon Americen colonies from the British crown, has commonly been laid upon George III, Lord North, and Grenville. This is not a just judgment.Doubtless they showed too little tact and understanding of the situation. But their claim that the colonists ought to make some contribution to the cost of their own defence was in itself fair, and the colonists were at least blind to the justice of this claim as the king was to their objections. (p.408).

The Trade System Causes Trouble

Although an honest attempt was made to balance the restrictions on colonial trade by monopoly rights for colonial goods in the English markets, and by bounties from the British Treasury on colonial production, 
and although the balance of advartage and disadvantage was about equal on both sides, it was nolther wise nor safo to base imperial unity upon trade-bonds. Moreover, the system wes not made by agreement, but solely by the authority of the British Parliament.....Although the colonists never formally attacked the trade-system, they only tolerated it as long as it was not onfor ced. It was, in fact,one or the main causes of the difficulty. (p.499).

System of Government in the colonies

The system of government, whereby the Gorrornom in each colony was appointed by the Crown but had to work with elected legislatures, was bound to work badly.(p.409)

The Problen of Defonce

It was reas onable that the home country, already loaded with debt, which had largely been incurred on bohalf of the colonies, should expect some contribution towards the cost of defence which this system threw upon it ; but the attempt to obtain this contribution was the immediate cause of the breach. (p.\$09-410).

The Wostarn Territories

The probleme presented by the new territories oast of the Miss 1ssipp1 which had recently been conquered from France were another cause of friction. The colonies regarded those lands as their property. and wanted a freo hand in dealing with them; the home government regarded them as Brit1sh conquests, and was resolved to administer them with a rogard for the rights of tholr Indian Inhebitants with which fow of the colonios had any sympathy. (p.410).

A Difficult Problem

The truth is that the colonies had grown up, and the system which had served for their 
ohildhood was no longer suitable. They onjoyod a higher gogree of freodom than any other colonies in the world, or than any other pooples in the world; and the freor a people 1s, the more 1t resents any restriction on its froedom. Fren in the sphere of trade, the restrictions imposed upon the British colonies were as nothing in comparison with the rigid control exercised by France, Spain, and Holland orer their colonies. It is merely absurd to say that the home government, corrupt and short-sighted as it was, was in any sonse tyrannieal. The problem which Goorge III and Grenvilie and North had to face was a problem far too difficult for them-a problem which oven Burke and Chatham nover fully appreciated, and which no colonial statesman understood-a problem which was now to the world. Itwas nothing less than the problem of enabling a number of free cormunitios to ilre together in unity without impairing the ereodom of any of them. It was not the imposition of a threo penny duty on tea that separated smerloa from areat Britain, but the impossibility, in that generation, with its traditions and background, of reconclling unity with liberty. (p.410).

\section{George Washington--A Great Man}

One thing alone maintained the colonial cause during the first years-m-the steadfastness of George Washington, their leader. He was the only great man produced by the war on elther side. (p.411).

Champions of the Americans

These two despotis porers, [France and Spain] which hed nover granted any semblance of solfgovernment to their own colonies, now $\operatorname{cam} \theta$ forward as the champions of the Amerlcans against the Mother-Country which had conferred upon them the highest degree of liberty enfoyed any peoples in the world. (p.415).

Death of Cha tham

He [Chatham] had to be carried out of the 
House after his speech, and died a few weoks later. Thus, in tho crisis of her fate, Britain lost the one man who might even yet have redeemed the situation.

The conduct of the war remained in the hands of the king and his now discredited ministers. They showed, as wo shall seo, no sort of competence in the conduct of the rar. $(p .415)$.

Fallure of the British Fleot at Yorktom

Off the mouth of Chesapeake Bay, ho [de Grasse] met an inferior British squadron, which ought to hare fought him to the death, but insterd drew off. (p.419).

Why the Finglish Falled at Yorktown

This sudden and disastrous revorsal of for tune [the surrender at Yorktorm] - which was ultimately due to Sandwich's mishandling of the navy--put an end to the poss1bility of victory in Amorica. (p.419).

The Constitution of the United States

Beceuse it was based upon a sort of treaty betweon thirte en independent states, the new constitution [of the United States] was the most rigid, and the most difficult to alter, that has ever controlled the affairs of a great state. But it was framed with such wisdom that it has stood the strain of noarly a century and a half, and has fitted the noods of a conmunity that has grown to be the biggest and richest of the world's socleties. (p.421).

Evatuation:

Mr. Muir fools that the American Revolution of 1776 was caused by keen misunderstanding on the part of the thirteen colonies as well as on the part of Great 
Britain. He lays the blame on each one. For instance, bo states that "doubtless they [Goorge III, Lord North, and Grenville] showed too little tact and understanding of the situation. But their claim that the colonists ought to make some contribution to the cost of their orm defonce ras in itself fair and tho colonists were at least blind to the justice of this claim as the king was to their objections." Again ho says that "the colonles regarded these 1 ands [those enst of the kississippl River] as their property, and wanted a free hand in dealing with them; the home government regarded them as Bitish conquests, and was resolred to administer them with a regard for the rights of their Indian inhabitants." And again he states that "although an honest attempt was made to balance the restrictions on colonial trade wy monoly rights for colonial goods in the English markets, and by bounties from the British Treasury on colonial production, and although the balance of adrantage and disadrantage was about equal on both sides, it was neither wise nor safe to base imperial unity upon trade-bonds."

Mr. Muir is willing to acknowledge that England lacked great men who were needed to handie this new situation. Grenville, he claims was "an industrious and thoughtful politician who had a great deal of 
kmowledge about Amerlcan affairs, and he did his best to deal fairly with the very difficult situation which the war Seren Yoars' War had raisod. However Chatham "had to be carried out of the House after his speoch, and died a fow weoks later. Thus, in the erisis of hor fato, Britain lost the one man who might even yet have redeemed the situation." He believes that the only truly great man of th is time was George Washington.

However, he states frequently that the American colonles "enjoyed a higher degree of Ireedom than any other colonies in the world," and that this very freedom led them to revolt against the mother-country. He states: "The freer a poople is, the more it resents any restriction on 1ts froodom."

English cabinet opinion about the attitude of the colonists in 1776 was about evenly divided. Mr. Mulr says that the duty on tea was retained by a majority of one. However, the bulk of the population did feel that the colonists were "unreasoneble."

The real trouble wes that noither English nor colonial statesmen understood the problem before them. Mr. Muir says: "The problem which George III and Grenv1lle and North had to faco was a problem far too difficult for them a... a problem which oven Burke and Chatham never fully approciated, and which no colonial statesman 
understood -.. a problem which was new to the world. It was nothing less than the problem of enabling a number of freo communities to live together in unity without impairing the freedom of any of them." The loss of the war is excused by the lack of great generals, and the mismanagement of the navy, and the assiatance given the American colonists by the Frenoh fleot.

In closing his section devoted to the American Revolution of 1776, Mr. Muir pays tribute to the Constitution of the United States. "It was framed w1th such wisdom," he says, "that it has stood the strain of nearly a century and a half, and has fitted the needs of a community that has grown to be the blggest and richest of the world's societies." 
Causes of the War as Iistod by Mr. Muir:

(1) Proclamation of 1763

(2) Molasses Act

(3) Smuggling

(4) St act

(5) Taxation w1thout representation

(6) Doclaratory Act

(7) Boston Massacre

(8) Quebec Act

(9) Boston Tea Party

(10)Lord North's Penal Laws

(II) Suspension of the charter of Massachusetts

(12)Governmentel system

(13)Removal of the French Menace

Persons Mentioned by the Author:

Brit1sh

(1) George III

(2) Marquis of Bute

(3) william Pitt

(4) Bolingbroke

(5) Duke of Newcestie

(6) John W1lkes

(7) George Gronvilie

(8) Duke of Bedford

(9) Lord Rockingham

(10) Edmund Burko

(II) Duke of Grafton
(12) Shelburne

(13) Charles Townshend

(14) Lord North

(15) Lord Sandwich

(16) Admiral Rodney

(17) General Cornwallis

(18) s1r Fenry Clinton

(19) General Gage

(20) Charles Fox

(21) Lord Howe

(22) John Burgoyne 


\section{Amerlcans and Amer Ican Allies}

(1) Benjamin Frankiln

(2) George Washington

(3) Horat10 Gates

(4) Bonedict Arnold

(5) Admiral do Grasse

Erents Mentioned by the Author:

(1) Battlo of Lexington

(2) Battie of Bunker's H1ll

(3) Eracuation of Boston by the British

(4) Invasion of Canada

(5) Capture of Charleston, S.C.

(6) Battlo of Brooklyn Helghts

(7) Occupetion of Ner York by the British

(8) Battle of Trenton

(9) Battle of Brandywine

(10) Occupation of PhIladelphia by the British

(II)Battle of Germantown

(12) Batt le of Saratoga

(13)Evacuation of Philadelphia by the British

(14) Capture of Savannah, Ga.

(15) Battle of Camden

(16)Battle of Gulldford Court House

(27) Surrender at Yorktown

The Most Important Event of the War in the Opinion of the Author:

(1) Battle of Saratoga 
Results of the War Mentioned by the Author:

(1) Britain rocognized the independence of the thir teen American colonies.

(2) Britain coded to the American colonies all the territory east of the Miss issippl River, except Florida.

(3) The American Revolution made the Fronch Revolution ineritable.

(4) A powerful freo republic, the Onited States, was created in the Now World.

(5) Floride was coded to Spain.

(6) France rodolved some small.1slands.

Ramsay Muir in his British History gives about 11,520 words to the discussion of the American Rerolution of 1776. This takes about 3.2\% of the space of the entire book. Two black and white maps, no illustrations, and no graphs are in the portion of the book given over to the American Revolution of 1776 . The print is rather smell and no effort has been made to arouse interest in pupils by the appeal of the book. 
IV- A Concise History of Britain - - by Robert M. Rayner Longmans, Green and Co. London, 1937.

In regard to the American Revolution of $1776, \mathrm{Mr}$.

Rayner states:

Extent of Colonial Government

It was taken for granted that laws passed by the Parliament at Wostminster wore current In the colonies, but in actual practice the colonists had complete self-government in all respects save one--the regulation of commerce. Certain colonial exports and imports had to pass through the Mother country, and could only be carried in British or colonial ships.

They were the freost commities in the world-cortainly no other Power allowed overseas possessions anything like such a degreo of independence. But they had inherited British ideas of liberty; and those 1deas, transplanted into new country, had developed much farther than in Ingland.... But the better off a people are, the better off they want to be. (p.113).

Causes of the Trouble

There were two main causes of the disagreement. Firstly, the colonists resented having officials sent out, ospecially as these were usually connected with the 'ruling class' in Britain, and therefore men of very different upbringing and outlook from their own. The colonial Assemblies sometimes refused to vote the salaries of these officials, and the result was a good deal of unseemly bickering. Secondly, the colonials did not dispute the right of the Home Government to regulate their trade--they simply ignored it, by carrying on wholesale smuggling. (p.413)

The Colonists Engage in Illegal Trade

The colonists had porsisted in their 1llegal trading with the Frenchinguring the mar [the Soven Yoars' War].....Moreorer, the war had doubled the National Dobt, but the colonies had contributed little or nothing towards 1ts cost, despito the fact it had been fought largely to save them from French aggression? (p.414). 
Charecterizetion of Grenvilie

As 111 luck would have 1t, the task of dealing with the problem fell to Grenville, a man whose training as a lawyor mado him clear-hoaded and logical rather than tactful and sympathetic towards other people's point of view. (p.414).

Why the Colonists Oppose the Stamp Act

The spokesman for the colonists did not claim that a Stamp Act was an unfair method of collecting revenue, or that it bore hervily on them.... It was the principle of the thing to which they objected. 'No Taxation without Representation' had been one of the watchwords in the nation's struggle for constitutional liberty. (p.415).

Cha racterization of Townshend

Then Charles Townshend, the clever but rockless young Chancellor of the Exchequer...stirred up the hornets' nest again. (p. 415).

George III Respons1ble for the Retention of the Tor Tax

Th1s exception [to reper] all duties but the ter tax] was made at the express desire of King George, who folt that it would maintain the general principle that his Govermment had the right to impose such duties.0r course, it was just this principle that the colonists were sis ting. (p.416).

England's Attitude Toward tho Boston Toa Party

This act of violence [Boston Ter Party] made the Home Government feel that it must do something drastic to restore respect for the law? (p.417).

Mr. Rarner's Comment on the Intolerable Acts

These penalties [Intolerable Acts] were needlessIy severe, and they gave the Boston ag1tators better grounds than they orer had before for declaring that King Goorge almed at destroying their liberty. (p. 418). 
Attitude in Fingland Torard the Colonists

The Wh1gs supported the Americans in Parliament,for they found the disptite an excellent excuse for attacking Lord North's Government. Burke brushed aside the question whether the Home Government had a constitutional right to tax the colonies; he simply asked the practical question, 'What good will you do trying to rule the colonies against their $\mathbf{1 1 1}$ ? This will end in your losing them altogether, for they cannot be hold by any other bond than that of affection and camon interest.' Lord Chatham, on the other hand, maintalned that the king had been in the wrong from the first, inasmuch 28 Parliament had no right to tax communities not represented in 1t. (p.417-18).

\section{Tribute to George Washington}

Whoreas the British had no leader of outstanding ability...t the Americans had the good fortune to find one of the greatest Heroes of the Nations. Goorge Washingtan, who was appointed to command the 'Continental Army', was a Virginia gentloman who had hold the King's commission during the Soven Yoars' War.H1s military training hed been very limited, and he was never a brilliant strategist; but the salient trait of his character was just what was required $f$ or the situation in which he was placod--a stoadlast spirit whlch upheld him in every sort of dis couragements reperted defeats in the fleld, treachery among his officers, wholesale deseptions by his men, a congress that so stinted him of supplies that his forces were of ten in rags, starving and half-armed. (p.419)

Comment on France's and Spa in's Inconsistency

It seemed somewhat absurd for these two despot1c Governments, [France and Spe in ]] which had never allowed their overseas possessions the least semblance of independence, to come forward as protectors of the British colonies which enjoyed a greater degree of self-government than any other community in the world. (p.422). 
Fngland Learns the Value of Sea-power

The cause of this sudden change [from seeming rictory to crushing defert] was an instructive example of the importance of sea-power. (p.423).

Eve luation:

Mr. Rayner stutes that there were two maln causes of the disagreement botween the colonists and the Home Government. "Firstly, the colonists resented having offlcials sent out" (from England to govern them), and secondly, the colonists"did not dispute the right of the Home Government to regulate their trade--they simply lgnored it, by carrying on wholesale smuggling." Both of these reasons lay the blame for the War on the colonists but somehow one feels that these reason are superflcial and that Mr. Rayner has not got at the root of the tter.

Mr. Rayner attributes the dissatisfaction of the colonists to their "British Ideas of Iiberty" which "had dereloped much farther than in England." He states that "In actual practice the colonists had complete selfgovernment in all respects save one-- the regulation of commerce" and that "they we the freest communities in the world. "In spite of all this, they seem to lack love for the Mother Country. During the Seven Years' War the colonists "persisted in their 1llegal trading with the French" and went so far as to "sell to the onemy goods 
that were urgently required for the British forces in Amer1ca." "Law-breaking and tax-dodging could not be allowed to go on forever." so English ministors undertook to deal with Amer 1ca.

"As 11 luck would have it, the task of dealing with the problem foll to Grenvillo, a man whose trainIng as a lawyer made him clear-headed and logical rather than tactful and sympathotic towards other people's point of view," and "Charles Townshend, the clever but reckless young Chancellor of the Exchequer...stirred up the homets' nest again," and "This exception[ropea] of all duties but the tax on tea] was de at the express desire of King George "arethree statements which show that Mr. Raynor realizes that Figland was handicapped by having no one wise enough to deal with a diffichlt siturtion.

At first one feels that Mr. Rayner is willing to I ay the entire blame for the American Revolution of 1776 on the colonists but as one reads on he finds Mr. Reyner sey ing, "The spokesman for the colonists did not claim that a stamp Act was an unfair mothod of collecting venue, or that it bore heavily on them.... It was the principle of the thing to which they objected. 'No Taxation without Roprosentation ' had been one of the watchwords in the nation's struggle for constitutional liberty." Again he states that the Intolerable 
Acts were "noedless ly severe" and "geve the Boston ag1tators better grounds than they had ever had before for declaring that King Goorge almed at destrojing their liberty." On the whole, then, it seems that Mr. Rayner acknowledges that both combatants were to blame for the trouble but the first impression that one gathers from his book is that only the colonists were at fault. More careful analysis seems to disprove this.

As for what made England lose the war, Mr. Rayner feo is that "the advantages were not all on one side." Although the English ary was in better shape than the Continental army, there romained the geographical foatures and the great loader, George Washington, to be reckoned with. He peys a glowing tribute to the colonial leader, calling him "one of the greatest Heroes of the Nations."

The war itself is carefully related as a series of facts. Probably the only statements which disclose the writer's foelings are "Chatham was now too old and 111 for such a task[loading tho country to victory]", and"the incompetent lordling to whom Georgo III had entrusted the Admiralty neglected Pitt's policy of keeping the enemy's fleets blockaded in their harbours." Both of these statements Imply a lack of men capable of dealing with the task before them. 
On the whole, Mr. Rayner endeavors to give a nonpartisan viow of the entiro subject, although it is unfortunate that at first his book appears to place all the responsibility for the war upon the colonists. 
Causes of the War Mentioned by Mr. Reyner:

(1) Navigation Acts

(2) Mercant1le System

(3) Old Colonial system

(4) Smuggling

(5) Stamp Act

(6) Taxation without Representation

(7) Townshend Acts

(8) closing of the port of Boston

(9) Suspension of the Massachusetts' Charter (10) Colonial Government

(II)Boston Massecre

(12)Boston Tea Party

Persons Mentioned by Mr. Rayner:

British

(1) George III

(2) George Grenvillo

(3) W1111am Pitt

(4) Lord Rockingham

(5)Charles Townshend

(6) Lord North

(7) Edmund Burke
(8) General Gage

(9) General Howe

(10)General Burgoyne

(II)George Rodney

(12)General Cornuallis

(13)Colonel Tarleton

(14)General clinton

\section{Amertcans and American Allies}

(1) Goorge Washington

(2) Benedict Amold

(3) Samuel Adams

(4) General Rochambeau

(5) Admiral de Grasse 
Eronts Mentioned by Mr. Rayner:

(1) Battle of Lexington

(2) Battle of Bunker Hill

(3) Occupation of New York by the British

(4) Battle of Brandywine

(5) Occupation of Philadelphia by the British

(6) Battle of Saratoga

(7) Capture of Cha rleston, S.C.

(8) Capture of Bavannah, Ga.

(9) Surrender at forktown

The Most Important Event of the War in the Opinton of the Author:

(1) Battle of Saratoga Mesults Ment1oned by the Author:

(1) Englend recognized the independence of the thirteon American colonies.

Mr. Raynor gives about 4320 words to a discussion of the American Rovolution of 1776 and this is about 2\% of his entire book. The book contains no illustrations nor graphs and its one in the American Revolution section is in black and whito. The print is easy to read but the book does not invite the interest of students since it is without plctures, colored maps or any other attract1ve fortures. 
V- A Concise History of Great Britain $\rightarrow$ by

D.C. Somervell

Q. Bell and Sons,

London, 1936 .

Concerning the Amer1can Revolution of 1776, Mr.

Somervell states:

The Mercentile Sys tem

Fngland's interest in these colonies[American] had been entirely commercial, anf from the time of Cromwell onwards parliament had been bullding up an elaborate system of trade restrictions, sometimes called the Mercantile System. The leading 1dea of this system (which all European governments applied, with variations, to their colonies) was that an mpire ought to be, as far as possible, a self-sufficing comercial unit; that the purpose of colonies was to supply to the mother country, and not to the mother country's rivals, products which the mother country was otherwise compelied to buy from forolgne rs; and that the colonies should take in exchange from the mother country, and not from the mother country's rivals, the goods which the mother country produced. (p.369).

Effect on Colonial Trade of Trade Restrictions

It was true that if colonial trade was hampered by many of the regulations, it was encouraged by others which excluded forelgn goods from Fingland in the interest of the colonial producer. (p.369)/

Mercantilo System Hinders New Fngland Colonies

In fact the system, applicable onough to tropical colonies whose products are necessarily quite different from those of the mother country, did not fit colonios whose climete and character were not very different from that of England. A colony was to supply what 
England lacked and to in return what England could supply. But New England... - was becoming much too like 0ld England. She wanted to manufacture her own hats and horseshoes, and found the Mercant1le system barring her way.(pp.369-70)

\section{Colonial Loyalty a Sentiment only}

There was in the colonies a strong sentiment of loyalty... but this loyalty was a sentiment only, and certainly did not include a docile respect for Acts of Parliament. These colonies were...small, self-contained settlements, easily irritated by any interference with their own affairs, and little interested in the larger affairs of the enplro.Moreover, they had boen taught that England undertook their defonce in return for the benerits derived from tho $1 r$ trade.... It was by tradition England's business to fight and the colonists business to trado, and the arts of smuggling served them very well in carrying on, at the helght of the war, a lucrative trade with their good friends the enemy.' (p.370).

Grenville's Plan

Goorge Grenvilie...was conscientiously oconomical. He determined to enforce the commerclal laws more strictly than befor $\theta$, to establish permanentiy a portion of the British army in America, and to raiso in America at least a part of the money nocessary for 1ts support. The colonists regerded the force as in part designed for the malntariance of British authority over themselves and the suppression of smuggling... If the presence of the force vas unpopular, the cost of 1t was worse, yet Great Britain, having conferred the boon of the conquest of Canada, mainly from her own pocket, could hardly have asked her own taxpayors to pay the whole cost of a permanent forco in America. (pp.370-71).

\section{Attitude of George III}

George III, through Lord North, was now in control of parliament and pollcy, and ho was 
not going to be frightened into abandoning

his rights. (p.372).

Boston Massacre

In 1770, the British troops, after severe provocation, fired on the Boston mob, and fito Bostonlans were 'massacred.' (p.372).

The First Continental Congress

\begin{abstract}
A soldier, Gage, was appointed Governor of the colony[rassachusetts]. But to this in turm, the Americans had their reply, and it was remarkable one. Twelve of the thirteon colonies sent delogates to what came to be known as the continental congress of Philadelphia. (p.372).

Ties Between Ingland and the Colonies Weaken
\end{abstract}

Never, it has been sald, was a great emplre sundered upon such a trivial pretext. The fact is, the ties which bound together the colonists and the mother country were already weak to the point of rottenness, so that a very slight strain sufficed to snap them. (p.372),

Attitude of colonists

on the colonial side the revolution was the work of an energetic but small minority. The bulk of the population was indifferent. (p.372).

P1tt's Att1tude

Pitt was a strong imporialist, and upheld the Mercantile System, but he agreod with the Amer 1cans in condeming the Stamp Act.' I rejolce that Amer lca has resdated,' he sa1d.P1tt falled to seo that the Mercantile System was as much the cause of that resistance as was the $\mathbf{S t a m p}$ Act, though 1t was much less talked about. (p.373). 
Burke's Attitude

Burke...sharply distinguished botwoen what was legal and what was expedient. The Stamp Act, he held, was perfectiy legal, and much that was said in America perfectly foolish; but was such a pollcy, worth its cost? The question,' he sald, 'Is not whether you have a right to make these people miserable, but whether it is not your interest to make them happy.' But Burke's policy was merely negative. ( $\mathrm{pp} .373-374)$.

Tribute to George Washington

Just before their victory at Bunker's Hill, the Americans took a step the importance of which they can hardly have realized. They appointed George Washington commander-in-chlef of their army.... Thus the rebels entrusted themselves to the leadership of one of the greatest men in history, and for the next six years of fighting (and sixteen subsequent years of troubled politics) ho carried them and their cause upon his back. (p.374).

\section{Signing of the Declaration of Independence}

Many signed the Declaration [or Independence] with reluctance, provoked to take the irrevocable step by the bad old English hab1t, so hateful to P1tt, of employing German mercenaries to fight Inglish battles. If the English employed Germans, the Americans would seek the help of France, and the Declaration was a definite bid for a French alliance. (p.375).

Attitude of Howe

Howe was an indifferent soldier, and, like some of the parliamentary commanders against Charles I, he was so anxious to secure a friendly compromise and reunion that he did not exert what littlo military talent he possossed. (pp.375-6). 
Fnd of the Amer 1oan Revolution

In 1871, owing to the mismanagement of BritIsh se power, Cornwallis was caught on the poninsula of Yorktown, In Virginia, between the American army and the French fleet. His surrender marked the end of the American war, not because further British effort was impossible, but because George III could find no more parliamentary support. (p.376).

Evaluation:

Mr. Somervell gives an unbiased presentation of the merican Revolution of 1776. He takes great pains to give both sides of the argument which existed bot tween the American colonies and the mother country. Ho says that "all European governments applied" the Mer cantile System to their colonies and implies that in this the Inglish colonies in Americe were no worse off than other colonies. However, he shows that the Mercantile System hampered the development of the New England colonies since "New England was becoming much too like Old England." The colonists had "a strong sentiment of loyalty" but this "did not include a docile respect for Acts of Parliament." The colonists "had been taught that England under took their defence in return for the benefits derived from their trade... It was by tradition England's business to fight and the colonists' business to trade." "Britain, haring conferred the boon of the conquest of Canada, mainly from her own pocket, could hardly 
ha ve asked her own taxpayors to pay the whole cost of

a permanent force in America! Each of these is a fair statement of the facts existing in the case. Mr. Somervell states that the break between the American colonies and the mother country was based on a"trivial protext." But the real truth was that the "ties which bound the colonists and the mother country were already weak to the point of rottennoss, so that a very slight strain sufficed to snap them." This statement reveals, probably, the fundamental cause of the trouble between Fingland and the American colonies.

Ne1ther the colonists nor the English were entirely united in their attitudes toward the rar. "On the colonial side the revolution was the work of an energetic but small minority... The bulk of the population was indifferent" while in England Pitt and Burke sided with the colonists, and others, like George III, were "not going to be frightened Into abandoning" their "rights." when the English hired German troops, many signed the Declaration of Independence "provoked" by the "bad old Finglish habit."

The author pays tribute to washington calling 
him "one of the greatest men in history."

The author also states, more as a fact than as an excuse, that Howe "did not exert what little m1litary talent he possessed." The end of the war came, "not because further British effort was impossible, but because George III could find no more parliamentary support."

It seoms that Mr. Somervell's A Conclse History of Great Britain, more than any of the ten books reviewed, presents the American Revolution of 1776 on broad fundamental lines. He views it objectively as an historic ovent and as an excellent student of history should. He endeavors to delve behind surface causes and results for those that are more fundamental. Nothing can be found in his account of the Americam Revolution of 1776 which could label him an Englishman or an American and that is as it should be. His history is an excellent work. 
Causes of the War as listed by the Author:

(1) Governmental system

(2) Mercantile System

(3) Smuggling

(4) Manufacturing Act

(5) Establishment of a Standing Amy in America

(6) Navigation Acts

(7) Removal of the French Menace

(8) Stamp Act

(9) Taxation withput Representation

(10)Boston Massacro

(11)Boston Tea Party

(12)closing of the port of Boston

(13) Suspension of the Hassachusetts Assembly

(14)Lord North's Penal Laws

Persons Mentioned by the Author:

British

(1) George III

(2) William Pitt

(3) George Grenville

(4) Charles Townshend

(5) Lord North

(6) General Gage

(7) Dean Tucker

(8) Adam Smith

(9) Edmund Burke

(10)Sir William Howe

(11) John Burgoyne

(12)General Cornwallis

(13)Adm1ral Rodney

(14) Govermor Ell1ott 


\section{American}

(1) Samuel Adams

(2) George Washington

(3) Thomas Jefferson

Events of the war Mentio ned by the Author:

(1) Battle of Lexington

(2) Bat tle of Bunker H111

(3) Evacuation of Boston by the British

(4) Occupation of New York by the British

(5) Battle of Saratoga

(6) Battle of Brandywine

(7) Occupation of Philadelphia by the British

(8) Surrender at Yorktown

The lost Important Event of the War in the Opinion of the Author:

(I) Battle of Saratoga Results of the Nar listed by the Author:

(1) Minorca and Florida are ceded to Florida.

(2) France receives some small islands.

(3) The independence of the American colonies is acknowledged.

(4) The colonies recelve the territory between the Mississippl River and the Alleghanies.

Mr. Somerveli's book, A Concise History of Great

Britain is in two volumes. Each volume is small, light, easy to handle and has very good print. The book has no 
plctures and only a few black and white maps. There is nothing about it to entice the student to $100 \mathrm{k}$ into it. Mr. Somervell devotes approximately 3610 words to the American Revolution of 1776 and this subject takes up about $1.4 \%$ of his entire book. 
AMERICAN HISTORIES

VI- Our Nation's Development $\cdots$ by

Eugene C. Barker, William E. Dodd and Henry Steele Commager

Row, Peterson and Co., Evanston, Illinois, 1934.

The authors state in regard to the American Revolu-

tion of 1776:

Colonial Resentment at Effort to Tax Them

The colonists, too, expended large sums and incurred hoav debts [in the French and Indian War.] This fact caused them to resent all the more, the efforts of the imperial government to tax them after the war. Aside from the principle involved, they felt that they had already paid their fair share of the war expenses. (p. 67$)$.

Fingland W1shes the Colonists To Help Pay War Debts

The War[French and Indian War]greatly increased the British national debt. The ministers believed, and rightiy onough, that the results of the war were beneficial to the colonies. For the benefits which they had recelved and for the continued protection which they would onfoy from the maintenance of garrisons in the conquered territory, the ministry thought they should be willing to pay. It was this conviction which suggested the policy of taxing the colonies, a policy which brought on the Revolution. (p.68).

Causes of the Revolution

The Revolution grew out of two fundamental causes:(1) The development in England and the colonies of divergent political ldeas and practices; (2) The conflict of econnomic interests. It is not always possible to distingulsh betwoen political and oconomic causes. 
Did the colonists object to thestamp Act because they did not wish to pay the tax, an economic motive, or because of the politioal conviction that Parliament sould not legally tax them without their consent? The best that we can do is to say that a combination of the two causes led to the Revolution. (p.73).

Divergence of Political Idess

The chlef difference between American and Inglish political ideas centered in the theory and practice of legislative representation. A member of a colonial legislaturo... represented a local district. He must live in the district that he redresented, and none but residents of that district could vote for him. A voter could rote only in the district where he lived. There was thus a falrly close relation between the interests of the representative and the interests of the voters....

In Fingland the political practice was different..... member of the House of Commons need not live in the district that he represented. Nor need the voters who elected him live there. He rogarded himself as the representative of all the people of the British Empire. How, then, he asked, could the colonists deny that they were represented ? by the House of Commons? The colonists did deny 1 t, and gave reasons for their den1al, but to the Englishman their arguments seomed mero quibbling. (p.73).

Divergence of Economic Interests

Sooner or later they [the colonists] were bound to resent the navigation laws and demand the right to buy their imports and sell their exports to their onn best adrantage. (p.74).

Fngland Thinks Colonists Should Help Pay War Dobts

At the close of the French and Indian War, England's public dobt was greatly inoreased and its American territory onlarged. The Amerlcans had already borne a large share of the expense of the war in paying their own soldiers. Nevertheless, the government determined to raise in the colonies part of the money noeded 
to maintain garrisons in the newly acquired territory . (p.74).

Sugar Act Threatens New England's Cormerce

This Lar[Sugar and Molasses Act] threatened to destroy one of the most profitable

branches of New England Commerce. (p.75).

The Stamp Let Arouses Universal Opposition

The Sugar Act had afferted chiefly the commercial elements of the community. The Stamp Act struck at all classes... It aroused universal opposition. (p.75).

Statement of the Stamp Act Congress

The stamp Act Congress drew up a strong statement, declaring that it was the right of the colonists solely to tax themselves.... 'The people of these colonies,' said the Declatetion of Rights, 'are not, and from their local circumstances, cannot be represented in the House of Commons in Creat Britain;.... and no taxes....can be constitutionally imposed on them but by their respective legisiatures'. $(\mathrm{p} .76)$.

How Englishmen Felt About the Stamp Act

Englishmen were by no means persuaded that the tax [Stamp Act]was unconstitutional, but they were now convinced that it was inexpedient. ( $p .77)$.

Retention of the Tea Tax

This tax [the threepenny tax on tea] was retained as an assertion of the right of Parliament to legislate for the colonies 'In every way whetsoever.' (p.78).

No Peaceful Solution Possible

It is evident to us now that no peaceful solution of the difficulty was possible. Neither the government nor the colonists were in the humor to compromiso. (p.81). 
Dofeat of Pitt's Motion

In the House of Lords, William Pitt, now Lord Chatham, moved the recall of the troops from Boston, but his motion was defeated by a rote of nearly three to one. Then ho moved the repeal, on certain conditions, of all the laws that were objectionable to the colonists, but this was rejocted two to one. (p.82).

Attitude of the Members of Congress

Members of Congress did not belleve that a reconciliation with England was impossiblo. They were not yet ready to make a doclaration of independence. On the contrary, they drew up a statement saying that they had taken up arms in defence of their freedom and their property, and again petitioned the King to recognize their rights and stop the abuses of which they complained.

Neither the King nor Parliament, however, was willing to make any promises while the colonists were in arms. (pp.83-84).

Why the Indictment of George III Appears in the

Declaration of Independence

The short, crisp indictment of the king in the second section [of the Declaration of Independence] was a terse review of the causes of the quarrel with the mother country since 1761. Jefferson wrote it to prove that The h1story of the present King of Great Britain is a history of repeated injuries and usurpations, all having in direct object the estabilshment of an absolute tyranny over these States.' (p.87)

Colonists Refuse Lord North's Peace Offer

Lord North, the English prime minister, offered to make peace in 1778 by granting the Americans everything they had demanded including the exclusive right to vote their own taxes. Some years earlier they would 
have accepted such terms 8ladiy. Now they were flghting for independence, and France had just signed

the treaty of alliance, so ${ }^{\prime}$ the war went on.(p.95).

Evaluation:

For the most part, the authors state facts and leave the reader to form his own opinion regarding the facts. They stato that the cause of the war was due chlefly to different economic and political views held by the colonists and by the English. For Instance, the 1deas, held by the colonists and Great Britain, in regard to the debts incurred in the French and Indian War, differed greatiy. The colonists felt they had done their share by paying and supporting the colonial troops; the Fnglish government folt that the colonists helk

should pay for the expenses the mother-country had incurred in the war since the colonists benefited from therresults of the war.

The authors state exactly the difference of opinion which existed in regard to representation and show why there was so much misunderstanding about it. They point out that this difference of opinion, coupled with laws passed by England--Iaws which would ruin business in the colonies, must have of necessity brought a break between England and her American colonies. They atate that "it is evident to us now that no peaceful solution of the difficulty was possible." 
The writers discuss rather fully the various meetings, such as the Stamp Act Congress, the First and Second Continental Congresses, and the document which the second Continental Congress produced-- the Declaration of Independence. In these discussions, they simply lay the facts before the reader without seeming to try to influence his opintons.

All in all, these authors seem to endeavor to be fair to both sides. They make such statements as "The ministers belleved, and rightly onough, that the results of the war were beneficial to the colonies. For the benefits which they had receired and for the continued protection which they would enfoy from the maintenance of garrisons in the conquered territory, the ministry thought they should be willing to pay." Then, they balance it with such statements as "Moreover, it was inevitable that the Americans should sooner or later question the Inglishman's bellef that the colonies must be governed for the benefit of England." 
Causes of the $\operatorname{Mar}$ Mentioned by the Authors:

(I) Removal of the French Menace

(2) Sugar and Molasses Act

(3) Stamp Act

(4) Taxation without Representation

(5) Declaratory Act

(6) Townshend Acts

(7) Townshend's Penel Laws

(8) Boston Massacre

(9) Burning of the Gaspeo

(10)Boston Tea Party

(11)closing of the port of Boston

(12) Massachusetts Govermment Act

(13) Administration of Justice Act

(14)Writs of Assistance

Persons Mentioned by the Authors:

British

(1) Goorge III

(6) William Howe

(2) Cha rles Townshend

(7) John Burgoyne

(3) General Gage

(8) General Cornwallis

(4) William Pitt

(9) Lord Shelburne

(5) Lord North

(10)Richard Oswald 
Americans and American Allios

(1) James 0t1s

(2) Patrick Henry

(3) Christopher Gadsden

(4) Samuel Adams

(5) Thomas Jefferson

(6) Richard Henry Lee

(7) Paul Revere

(8) George Washington

(9) Benjamin Franklin

(10) John Adams

(11) Thomas Paine

(12) Roger Shermen

(13)Robert R. Livingston

(14)Richard Montgomery

(15) Benedict Arnold
(16) Charles Lee

(17) George Rogers Clark

(18) Francts Marion

(19) Thomas Sumter

(20) Andrew Plckens

(2I) John Paul Jones

(22) Count Rochambeau

(23) Marquis de Lafayette

(24) Baron von Steuben

(25) John Barry

(26) Thaddeus Kosclusko

(27) Basimir Paldert

(28) John JaJ

(29) Johann De Kalb

(30) Henry Laurens

Events of the Mar Listed by the Authors:

(1) Battle of Lexington

(2) Battle of Concord

(3) Captire of Crown Point

(1) Capture of Ticonderoga

(5) Battle of Bunker Hill

(6) Invasion of Canada

(7) Battles of Brooklyn Helghts, Harlem and Whito Plains 
(8) Battle of Trenton

(9) Battle of Princeton

(10)Battle of Brandywine

(1I) Occupation of Philadelphia by the British

(12)Battle of Gormantown

(13)Battle of Saratoga

(14)Battle of Monmouth

(15) Capture of Kaskask1a

(16) Capture of Vincennes

(17) Battle of Camden

(18)Battle of King's Mountain

(19)Battle of Cowpens

(20)Battle of Gullaford Court House

(21) Surrender at Yorktown

(22) Capture of the Serapis

The Most Important Event of the War in the Opinion of the Authors:

(1) Battle of Baratoga

Results of the War Iisted by the Authors:

(1) The independence of the thirteen American colonies was recognized by England.

(2) The boundaries of the new United States were defined.

(3) The United States was given the right to navigate the Mississippi River from its source to its mouth.

(4) Certe in fishing of the New Fngland coast wore given to the United States. 
(5) The Americans agreod to interpose no legal obstacle to hamper English merchants in collecting debts due them from Americans.

(6) England agreed to remove 1ts troops from the territory of the United States.

(7) No provision was made for commercial relations between England and the United States.

Barker, Dodd and Conmager's Our Nation's Development gives about 7,770 words to the American Revolution of 1776, and about $3.8 \%$ of the total space of their book. The section given orer to the American Revolution contains three 1llustrations, three maps, and no graphs. Although the book conteins some colored pletures, the pletures and maps in this section are in black and white. The print is easily read, the paper is good and the book's arrangement invites further acquaintance with the book. 
VII- America: Its History and Peopbe -- by

Harold Underwood Faulkner and Tyler Kepner

Harper and Brothers, New York, 1934.

In regard to the American Revolution of 1776, the

authors state:

The Colonial Policy of European Countries

As far as the colonists were concerned, they existed primarily for the advencement of the home country, and their interests were generally hold to be subordinate to those of the mother country.... This colonial polloy was folloved by every colonizing power of Europe. (p.66).

The Colonial System Not Detrimental to Colonies

In spite of the fact that the Inglish colonial policy was essentially selfish and was concelved primarily for the benefit of the home country, it is nevertheless true that the effect was not markedly disastrous. $(p, 67)$.

Why the Revolutionary War Mas Fought

The Finglish ruling classes never questloned the justice or legallty of the varlous acts which thoy passed to accomplish this purpose[of lonitting the Impire more closely together], for these laws were in line with the whole policy of mercantilism which Hngland and all other European colonial powers had followed for a century. Although at the time there was much talk in America of justice and liberty and 'no taxation without representation', the Revolution was not fought primarily because of any riolation of the technicalloporers of the British government. It came because an igmorant and stupid administration with 
slight kmowledge of the American problem and no understanding whatsoever of the American mind passed law after law, which in the abstract might bo logal and perhaps just, but in tho concrete simply goaded the colonists into action, and fanned to a flame the longsmoldering resentment against the whole British colonial system. $(p .69)$.

Proclamation of 1763.

The purpose of the Proclamation [of 1763] was chiefly to regulate the westrard movement in a more orderly manner and thus avold Indian trouble; but the colonists felt that Fingland was hampering the normal development of colonial expansion in order to keep the settlements east of the mountains firmly under her control. (p.70).

British Had Law on Their Side

Whatever might have been the wisdom of ading more duties, the British position seemed to be legaliy corvect. (p.70).

Attitude of Colonists Toward British Regulars

The sending of regulars to America in times of peace was $100 \mathrm{ked}$ upon as a method of overawing the colonists at a time when obnoxious laws were being pessed. (pp. 70-71).

Townshend's Mistake

With a cocksureness born of Ignorance of imerica, he [Tomshend]at once proposed to increase the revenue obtained from America by new taxes. (p.72).

Attitude of the Colonists Toward Taxation by British

In reality the colonists objected to being taxed at any time, in any way or by any body. To many Americans the benefits of govermment seomed to be slight, and they rareiy saw any of the currency with which the taxes were paid. If they objected to being taxed by their own colonial governments, it inas natural that 
they should resent taxes levied by an authority beyond the seas. (p.72).

The British Blunder

The efforts of these radical leaders, [Samuel Adams, Patrick Henry and Thomas Jefferson] nevertheless, might have been of no avall if the British government had not blundered again.(p.74).

Qovernor Hutchinson's part in the Drame

He [Govermor Hutchins on] seemed intent upon forcing the issue. (p.75).

The Colonists Conderm the Violence of the Boston Tea Party

This act of violence[Boston Tea Party] was widely condemed in the colonies, and can be oxcused only on the ground that a break was ineritable, and the sooner it could be precipitated the better. (p.75).

Attitude of Colonists at First Continental Congress

The colonists[at the First Continental Congress] were about equaliy divided on the legality of Parliament's right to regulate external commerce.(p.76).

Att1tude of Colonists in 1775

By 1775 the American colonies had reached the stage where they would no longer subordinate their own interest to those of Great Britain or the mpire as a wholo. British imperialists thought they were solfish; but the colonists felt they must protect their own interests. (p.77).

Why the Declaration of Independence Is Great

The Declaration of Independence is one of the great landmarks in history not merely becauso it announced the birth of an independent AmerIcan nation, but also because 1ts ringing words were to be a perpetual challenge to despotism and divine-risht rule, and a perpetual reminder that 'govermments derive their just powers from the consent of the governed.' (p.85). 
Why the Colonists Won the War

Why was it that the colonists finally won? The American Revolution of 1776] Four factors holp to explain the result: (1) the goographical nature of the problem, (2) the stupidity of the Fnglish war office, (3) ald from France, (4) the unfaling courage and dogged persistency of Washington and his soldiers. $(p, 86)$.

Tribute to Howe

Howe's campaign[attask on New York] was well concelved and energetically executed. (p.87).

Why the British Lost at Baratoga

This was a beautiful plan, [to cut the New Fingland colonies off from the other colonies, but it was folled by the negligence of the British war office and the valor of the American militia. (p.88).

Evaluation:

The authors appear to belleve that the American colonies were treated in the same manner that all other colonies were treated in that period of history by their mother countries. However, they state that it was natural for them eventually to resent the use of their territory and of themselves primarily for the advancement of Great Britain. They feol that the cause of the war was due to "an ignorant and stupld administration with slight knowledge of the American problem and no understanding whatsoover of the American mind" which "goaded" the colonists into action against the mother country by 
passing law after law which the colonists resented. In the passing of these laws, they state that the British were probebly within their legal rights but they certainly lacked wisdom. As they see 1t England "blundered" time and again. However, they deplore the part the colonists played in the Boston Tea Party saying that their actions "can be excused only on the ground that a break was inevitable and the sooner it could be preclpitated, the better."

As regards Great Britain's losing the war, they claim that this was due chiefly to the "stupidity of the English war office." They state that some of the war plans of the British were "beautiful" but they failed frequently because of the "negligence of the British war office."

The authors give much space to the various Congresses held by the colonists and to the analysis of the Deciaration of Independence. They mention quite a number of characters and events. They claim that the American Revolution of 1776 had "far-reaching economic and social effects." 


\section{Causes of the War Yeationed by the Authors:}

(1) Navigation Acts

(2) Manufacturing Act

(3) Smuggling

(4) Molasses Act

(5) Proclamation of 1763

(6) Sugar Act

(7) Establishment of standing in America

(8) Stamp Act

(9) Taxation without representation

(10)Writs of Assistance

(II) Doclaratory Act

(12) Townshend Acts

(13) Boston Massacre

(14)Boston Tea Party

(15)Closing of the port of Boston

(16) Suspension of the Massachusetts Charter

(17) Penal Laws

(18) Quartering Act

(19)Quebec Act 


\section{Persons Mentioned by the Authore:}

\section{Br1t1sh}

(1) Sir Robert Walpole

(2) George Grenville

(3) George III

(4) Horace Walpole

(5) William Pitt

(6) Charles Townshend

(7) Lord North

(8) General Gage

(9) Sir William Howe
(10)General Carloton

(II) Lord Cornwallis

(12) Lord Germaine

(13) John Burgoyne

(14)Sir Henry Clinton

(15) Colonel Tarleton

(16)Governor Hamilton

(17)Governor Hutchins on

(18) colonel st. Leger

\section{Americans and American Allies}

(1) James Otis

(2) John Adams

(3) Patrick Henry

(4) Samuel Adams

(5) John Hancock

(6) Thomas Jefferson

(7) Roger Sherman

(8) Philip Livingston

(9) John Dickinson

(10) Joseph Galloway

(II) George Washington

(12) the Rutledges

(13) Ben jamin Franklin

(14)William Dawes
(15) Paul Rovero

(16)Ethan Allen

(17)William Prescott

(18) Richard Montgomery

(19)Benedict Amold

(20) Thomas Paine

(21)Richard Henry Ioe

(22)General Putnam

(23)General Harkimer

(24) John Stark

(25) George Rogers Clark

(26) Thomas Sumpter

(27)Francis Marion

(28)Andrew Plckens 
(29) Dhtizip.Schuyler

(30) Horat1o Gata

(31)Lincoln of Mass .

(32) Morgan of $\mathrm{Va}$.

(33) Silas Deane

(34) Marquis de Lafayette

(35) Johann De Kalb

(36) Casimir Pulaski

(37) Baron von Steuben

(38) Thaddeus Kosclusko
(39) Admiral de Grasse

(40) Count Rochambeau

(41) John Sevier

(42) Nathanfel Greene

(43) John Jay

(44) Henry Laurens

(45) John Barry

(46) John Paul Jones

(47) Robert Morr18

(48) Hayn Solomon

Events Mentioned by the Authors:

(I) Batt Io of Ioxington

(2) Battle of Concord

(3) Capture of Ticonderoga

(4) Capture of Crown Point

(5) Battlo of Bunker Hill

(6) Burning of Falmouth Harbor and Norfolk

(7) Invasion of Canada

(8) Evacuation of Boston by the British

(9) Battles of Brooklyn Helghts, Harlem and White Plains

(10)Battle of Trenton

(11) Battle of Princeton

(12) Fail of Oriskany

(13)Battle of Saratoga

(14)Battle of Bennington

(15)Battle of Brandywine 
(16) Occupation of Philadelphia by the British

(17)Battle of Germantown

(18) Evacuation of Philadelphia by the British

(19)Battle of Monmouth

(20) Capture of Kaskaskia

(21) Capture of Cahokia

(22) Capture of vincernes

(23) Capture os Savannah

(24) Capture of Charleston

(25) Battle of King's Mounta in

(26)Battlo of camden

(27) Surrender at Yorktown

(28) Capture of the Serapis

The Most Important Event of the War in the Opinion of the

Authors:

(1) Battlo of Saratoga

Results of the War Mention od by the Authors:

(1) The independence of the American colonies was recognized.

(2) The boundaries of the UnIted States were fixed.

(3) The M1ssiss1ppi River was open to the commerce of both Fingland and the United States.

(4) The United States was given fishing rights off the Now Fingland coast. 
(5) The United States Congress agreed not to hamper English merchants in collecting debts owed them by Americans.

(6) Due to the boycott and the British blockade, manufacturing began in the United States.

(7) The former governing class of arfstocrats was replaced by a new group of people in the United States.

(8) Bills of Rights appeared in the new state constitutions guaranteoing certain fundamental rights to citizens.

(9) Laws were passed assuring religlous freedom.

(10)Certain laws, such as those of primogeniture and enta1l, were abolished.

Faulkmer and Kepner's America: Its History and People devotes about 12,480 words and $4.2 \%$ of the total book's space to the American Revolution of 1776. The section given to the American Revolution contains one graph,two black and white maps, and seven black and white 1llustrations. The book's print and pages are large and on the whole it arouses the interest of the reader by 1ts mere appearanco. 
VIII- History of the American People -- by

David Saville Muzzey

Ginn and Company, Bost on, 1929.

In regard to the American Revolution of 1776, the

auth or states:

Removel of the French Menace

For the American colonies it [the ond of the French and Indian War] meant the removel of the French and Indian menace, and, therew1th, the end of further need of dependence on England for defence. (p.104).

The Complex Nature of the Revolution

The roots of the Revolution were deep and they grew out of a soll prepared for generations by the relation of the colonies to the mother country.... It was not a sudden spirit of rebellion that animated the colonies but a deep-seated determination to defend agelong liberties which the s saw threatened. (p.106).

The Cause of Colonial Ill Will Toward Fngland

The cause of this remarkable change in affairs [from the good feeling which existed at the end of the French and Indian War to the 11 f felling at the time of the Revolution] was a serlos of acts passed by the British Parliament which inaugurated a new policy in dealing with the American colonies and which led from protest and potition on the part of the colonies to disobedience, defiance, armed resistance, and finally Independence. (p.107).

\section{George III}

The young king, George III, had neither the disposition nor the ability to be a 'tyrant.' He was too poorly educated to be a statesman, but he was a diligent politician, determined in his obstinate way to control the whole machinery of government. (p.107). 
The Colonial Burden in the French Wars

Some of the colonies had already bome more than their share of the burden of the French

wars both in men and money. (p.108).

Attitude of Some Parliament Members

There were members of the Brit1sh Parliament... who understood the situation and opposed taxing America. (pp.110-111).

Townshend's Ability

Townshend had no understanding of the American question. He had voted for the Stamp Act and for 1ts repeal with equal complacency. (p.113).

The British Ministry Blunder

However, even Samuel Adams, by his persistent quarrels with Governor Hutchins on, and Thomas Jefferson, with his plan of intercolonial committees of correspondence, might not have been able to revive the 'flame of liberty' had it not been for a fresh act of folly on the part of the British ministry. (p.116).

Punishment of Mass a chusetts

Hither to the measures of the British government had been prompted by the desire to bring the colonies into a closer union with the mother country, not to alienate them further by harsh treatment. The violation of the king's laws, the deflance of the king's officers, and even the destruction of the king's property in America had gone unpunished. But the colonies were still the 'chlldren' of Great Britain, however 'unhappy and deluded' they might be; and like children they should be treated with firmness, tempered by Indulgence. When the news of the destruction of the tea arrived, however, Parliament decided that the time for indulgence was over. Massachusetts must be severeif punished as an example to the other colon1es. (pp.116-117). 
Reconcling Liberty with Loyalty

After a century and a half we can, without any sacrifice of grateful admiration for the Fathers of our country, view the events which lod up to the Revolution in a spirit of fairness to both sides.... The whole question was whether liberty could be reconclied with loyalty. Liberty meant to the colonists the right to direct their own affairs in the now country which had been bullt up, to extend their commerce without hindrences, to control their officials, and above all to vote their taxes in the ir own elected assemblies. Loyalty meant to the English obedience to the Acts of Parliament, which was the supreme authority of the Impire. These two views could not be reconclled..... Inglishmen today generally recognize that the Americans of 1775 were contending for a higher 1deal of British freedom than were the ministers of George III. They honor George Washington as a hero rather than condem him as a rebel. (p.121).

Declaretion of War

On July 6 it [the second continental Congress] issued a spirited declaration setting forth the causes for taking up arms. 'We are reduced to the alternative of choosing an unconditional submission to the tyranny of Irritable ministers or resistance by force. The latter is our cholce.We have counted the cost of this contest and $f$ ind nothing so dreadful as voluntary slavery.0ur cause is just, our union is perfect.... In defence of the freedom which is our birthright, we have takerl up arms. Wo shall lay thom down when hostility shail cease on the part of our aggressors. (p.122-23).

The Nature of the Conflict

The American Revolution from a military point of view was a group of little wars rather than a single war. The one integrating force was the person of the great com- 
mander, but George Washington held the army and the cause together by his exhaustless patience and courage rather than by any comprehensive plan of war. (p.130).

Cornwallis Pays Tribute to Washington

When Cornwall is made the final surrender of the British arm to Washington at Yorktow, he complimented the American commander upon his 'unsurpessed performance' in New Jersey. (p.133)

The Sword and the Olive Branch

The plain fact is that the commander of $\mathrm{K}$ ing George's forces did not wish to conquer the Americans by the sword. He [Howe] was a Whig (though the king's cousin) and he had promlsed his constituents in Fingland that he would win the Americans by persuasion and pardon. (p.133).

Evaluation:

Mr. Muzzey writes his account of the American Revolution from the American viewpoint. The colonists, ho claims, were defonding "age-long liberties which they saw threatened"; their 111 feeling toward the mother country was caused by "a serles of acts pass-d by the British Parliament which Inaugurated a new pollcy in dealing with the American colonies"; George III "determined in his obstinate way to control the whole machinery of government, "өtc..

There were some "members of the British Parliament.... who understiod the situation" but "Townshend 
had no understanding of the American question" and Fngland committ od fresh acts "of folly". "Englishmen today generally recognize that the Americans of 1775 were contending for a higher ldeal of Britlsh freedom than were the ministers of George III."

He calls attention to the admiration which Cornwallis had for George Washington and mentions that Cormwallis gave volce to this fooling on the occestion of his surrender at Yorktown. Englishmen today, he says, "honor George Washington as a hero rather than condemn him as a rebel."

Even when Mr. Muzzey states that after "a century and a half" we can be fair to both sides, he says that "the colonies were determined not to sacrifice their liberty to imperial unity, however much they prized that unity. And it was not until the middle of the nineteenth century that a more representative and democratic Parliament in England began to learn how to preserve the loyalty of its overseas domintons by granting them the very liberties which had been denied to the Americans."

Mr. Muzzey discusses the various congresses held by the Americans in their endeavor to meet Fngland as a unit instead of as thirteen separate colonies and he takes time to analyze the Declaration of Independence. Plans of varlous campalgns 
are also given at length. He mentions many persons who participated in the war as well as a number of the events of the war.

But after reading his account of the American Revolution of 1776 , one is impressed withthe fact that he almost 1gnores England's side of the argument. He makes one feel that the colonists were right first, last and always and that the Englishmen of today acknowledge this. 
Causes of the War Mentioned by the Author:

(1) Proclamation of 1763

(2) Navigation Acts

(3) Acts of Trade

(4) Molasses Act

(5) Sugar Act

(6) Establishment of a standing army in America

(7) Stamp Act

(8) Taxation without representation

(9) Writs of Assistance

(10) Doclaratory Act

(11) Townshend Acts

(12) Smuggiling

(13)Boston Massacre

(14) Burning of the Gapsee

(15) Boston Toe Party

(16)closing of the port of Boston

(17) Suspension of the Massachusetts Charter

(18) Quebec Act

Persons Mentioned by the Author:

British

(1) George III

(2)William Pitt

(3) George Grenville

(4)Edmund Burke

(5) Charles Fox
(6) Governor Hutchins on

(7) Governor Colden

(8) Charles Townshend

(9) Governor Bermard (10)Lord North 

(11) General Gage
(21) Hajor Andro
(12) Major P1tcairm
(22) Admiral Graves
(13) General Howe
(23) Colonel Hamilton
(14) Henry Clinton
(24) Lord Rockingham
(15) John Burgoyno
(25) RIchard Oswald
(16) Lord Cormwallis
(26) Lord Shelburne
(17) Lord Germain
(27) ? Camden
(18) Colonel st. Leger
(28) ? Conway
(19) Guy Carleton
(29) ? Barro
(20) Patrick Fergus on
(30) ? Phillips

\section{Americans and American Allies}

(1) Danfel Boone

(2) James Otis

(3) Benjamin Franklin

(4) Richard Henry Loe

(5) Patrick Henry

(6) Samuel Adams

(7) Thomas Jefferson

(8) Goorge Washington

(9) John Adams

(10) John Dickinson

(II) Joseph Galloway

(12) John Jay

(13)Philip Livingston
(14) Roger Sherman

(15) Christopher Gadsden

(16) the Rutledges

(17) John Hancock

(18) Parson Jonas Clark

(19) William Dawes

(20) Paul Revero

(21) Captain Parker

(22) William Prescott

(23) Ethan Allen

(24) Richard Montgomery

(25) Benedict Amold

(26) Ward of Rhode Island 
(27) Thomas Paine

(28) Edmund Randolph

(29) George Rogers Clark

(30) John Barry

(31) John Paul Jones

(32) Nathan Halo

(33) Charles L Le

(34) John Stark

(35) General Herkimer

(36) General Gates

(37) General schuyler

(38) General Morgan

(39) Count d'Estaing
(40) Marquis de Lafayetto

(41) General Lincoln

(42) John Sevier

(43) Thomas sumter

(44) Andrew P1ckens

(45) Francis Marion

(46) Nathaniel Groene

(47) Admiral de Grasse

(48) Count Rochambeau

(49) Thaddeus Kosciusko

(50) Count Pulask1

(5I) Baron de KaIb

(52) Baron von Steuben

Events Mentioned by the Author:

(1) Battle of Lexington

(2) Battle of concord

(3) Battle of Bunker Hill

(4) Capture of Ticonderoga

(5) Burning of Falmouth Harbor

(6) Invasion of Canada

(7) Battle of Brooklyn Helghts

(8) Battle of Trenton

(9) Battio of Princeton

(10)Battle of Saratoga

(11)Battle of Brandywine

(12)Battle of Germantown 
(13) Occupation of PhIladelphia by the British

(14) Battle of Bennington

(15) Dofeat at Oriskany

(16) Evacuation of Philadolphia by the British

(17) Battle of Monmouth

(18) Capture of Savannah

(19) Capture of Charleston

(20) Battle of Camden

(21) Battle of King's Mountain

(22) Surrender at Yorktown

(23) Capture of Kaskaskia

(24) Capture of Cahokia

(25) Capture of Vincennes

The Most Important Event of the War in the Opinion of the Author:

(1) Battle of Saratoga Results of the War Montioned by Mr. Muzzey:

(1) England recognized the independende of the American colonies.

(2) The Mississ ippl River was fixed as the western boundary of the United States.

(3) The Mississippi River was open for navigation to both England and the United States.

(4) The Americans were to share in the Newfoundland f1sherios. 
(5) The United States was not to hamper the BritIsh merchants in collecting the debts owed them by Americans.

(6) The social "class" distinctions began to be broken down.

(7) An attempt was begun to develop manufacturing in the United States.

(8) The Un1ted States was practically bankrupt.

Muzzey's History of the American People gives about 14,760 words or about $6.2 \%$ of the total book space to the American Revolution of 1776. The thirteen pictures and six maps in the American Revolution section are in black and white. No graphs appear. The print is easily read and the many pictures and maps make the book inviting. 
IX- History of the United States -- by

Charles A. Beard and Mary R. Beard

MacMillan Companz, New York, 1929.

About the American Revolution of 1776, the authors

state the following:

Polltical Partios and Goorge III

It is well to remember that King George was not solely responsible for the acts of the British government.... Since it was customary to transact official business in the king's name, George got far more blame than he realiy deserved. (p.114).

British Parliamentary System

Though the members of the House of Commons were elected by popular vote, they did not represent the masses of the people.C1ties like Leeds, Manchester, and B1rmingham, for examplo, had no representatives at all.(p.114).

Grenvillo and the War Debt

More taxes were absolutely necessary and the search for money finally led to America.... Hitherto the Americans had paid the salaries of royal governors and judges, thus keoping them under a certain control. According to the new system the Crown was to pay these salaries and Parliament was to tax the American people. (p.115).

\section{The Sugar Act}

Since the heavy debt under which England was laboring had boen largely incurred in the defense of America, it seemed reasonable to them that the colonies should take some of the burden off the backs of the English taxpayers. (p.116). 
Enforcement of Trade and Navigation Laws

All British officers in Americe wore instructed to be diligent in enforcing the trade and navigation laws.Revenue collectors, officers of the army and navy, and royal governors were curtly ordered to the front to do their full duty in this matter. Their sense of duty was quickened by an appeal to their selfishness, for naval offlcers who selzed offenders against the law were rewarded by large prizes out of the forfe1tures and penaltios. (p.II7).

Colonel Barre's Prophecy

'Belleve me--remember I this day told you 80 ', he[Colonel Barre] exclalmed, 'the same spirit of freodom which actuated that people at first will accompany them still.... people jealous of their liberties and wo will vindicate them, if ever they should be violated.' The answer of the ministry to a prophecy of rebelilion was a threat of farce. (p.119).

Grenvillo's Attitude

'America must leam,' he [Grenville] wailed, 'that prayers are not to be brought to Caesar through riot and sedition.' (p.122).

Townshend Fa1ls To Learn By Experience

Learning nothing from the experience with the Stamp Act, Townshend now pushed through both Houses of Parliament three new laws affecting American trade. (p.123).

Resentment Over the Writs of Assistance

To allow a 'minion of the law' to enter at will a man's house and search his papers and premises was too much for the patience of peoplo who had fled to America in quest for self-government and free homes, who had braved such hardshlps to ostablish liberty, and who wanted to carry on their business without officlal interferenco. (p.124). 
Enforcement of the Intolerable Acts

To enforce these Acts [Intolerable Acts] the military strengbl of the British government was brought into play. The commander-in-chief of the armed forces in Amerlca, General Gage, was appointed governor of Massachusetts. More soldiers were shipped to the colonies, for now King George was to give the 'rebels', as he called them, a dose of strong medicine. The majesty of his law was to be upheld by arms . (p.130).

The Greatness of the Declaration of Independenue

The secret of 1ts [the Declaration of Independence's] greatness Iies in the simple fact that it is one of the landmarks in history of a political 1deal which for three centuries has beentaking form and spreading throughout the earth, challenging kings and princes, shaking down thrones and aristocracies, and breaking the amies of irresponsible power on the battle flelds. That 1deal, now so familiar, then so novel, is summed up in the single sentence: Governments derive their just powers from the consent of the governed.' (pp.140-41).

Geographical Aspects of the War

From first to last the theater of operations extended from Massachusetts to Goorgia, a distance of almost a thousand miles. It was nearly three thousand miles from the main base of supplies in England, and bohind the coest line was a seomingly endless wilderness into which Amerlcans could rotreat.... Whonever the British ventured far from the ports of entry, they met reverses.... Ilving by their own labor, holding the intertor to which their armies could readily retreat, supplied mainly from native resources, the Americans could not be hemmed in, penned up, and destroyed by one fell blow or even by a series of battles. (pp.150-151). 
Sea Bower

The British of course made good use of their floot in cutting off American trade, but control of the sea did not serlously affect the United States at that time. (p.15l).

British Lose Supremacy on the Sea

British supremacy on the water could not be broken by American sea captains like John Paul Jones and John Barry, no matter how brilliant their exploits. They demonstrated the skill of American sallors and their courage as fighting men; they caused great losses to British shipping; but they could not dethrone the mistress of the seas.... Not until the French fleet was thrown into the scale did the British have to reckon seriously with the perils of maritime disaster. (p.151).

British Commanders

There is no doubt that all the British commanders were men of experience in fighting.... Though none of the British generals were men of first-rate ability, they all had training and experience to guide them. (pp.151-152).

George Washington

On the other side Americans had a tower of strength in their George Washington. He had long been interested in military strategy and had tested his coolness under fire during the clashes with the French nearly twenty years before.He had no doubts about the justice of his cause such as plagued some of the British generals and put a grag on their activity. Sterm, dogged, patient, he drove straight ahead amld victory and dofort. (p.152).

American Generals

of the gonerals who served under him[Weshington, none could really be called experlenced military men when the war opened.... Some had seen fighting with the French and Indians, but none of them had seen warfare on a large scale. 
Courage, natural ability, and quickness of mind they had in abundance, and in battles such as were fought in the Rovolution those qualities counted heavily in the balance. (p.153).

The Foreign Allies

To these distinguishod forelgners who freely threw in their lot with the revolutionists was due much of that spirit and discipline which fitted volunteers and militiamen to cope with British power. (p.154).

Why Did the Americans Win the War?

Then how did the American army actually win the war?for one thing there were delays and blunders on the part of the English generals who in 1775 and 1776 dallied in Boston and New York when they might have destroyed the scattered bands that made up the American army. 'Nothing but the supineness or the folly of the enemy could have saved us,' sald Washington in 1780. (p.151).

Evaluation:

The authors endeavor to relate facts and to do nothIng more in any way to influence one in forming an opinion. They make only carefully guarded statements such as,"It seemed reasonable to them [the English] that the colonies should take some of the burden of the backs of the English taxpayers" and,"This[the Boston Tea Party] was serious-.open, flagrant, determined violation of the law. As such the British government viewed it."

However they heap up the various offenses of the Crown toward the colonists, telling the reactions of the colonists to these offenses unt1l one is compelled to 
feel that the colonists were mistreated.

They state that Grenville cried, "America must learn that prayers are not to be brought to Caesar through riot and sodition" and that "learning nothing from the exper1ence with the Stamp Act" Townshend had his acts put through Parliament. They let their attitude about George III be clearly seen. They ask the reader to remember that "It was customary to transact officlal business in the king's name" and so "George got far more blame than he really deserved." They discuss at length the Stamp Act Congress, and the First and Second Continental Congresses. They analyze the Declaration of Independence. They pay glowing tributes to Washington and the many foreigners who cast their lot with the colonists. Meny events and persons are mentioned in the course of the discussion. But the two chapters devoted to the American Revolution reveal very little to influence one in forming an opinion. 
Causes of the War Mentioned by the Authors:

(1) Grenville's Restriction of Paper Money

(2) Proclamation of 1763

(3) Sugar Act

(4) Stamp Act

(5) Taxation without representation

(6) Smuggling

(7) Molasses Act

(8) Trado Acts

(9) Navigation Acts

(10)Quartering Act

(11) Declaratory Act

(12) Townshend Acts

(13)Writs of Assistance

(14) Closing of New York's Assembly

(15)Boston Massacre

(16)Boston Tea Party

(17) "Lexington of the South"

(18)Burning of the Gaspee

(19)closing of the port of Boston

(20)Suspension of the Massachusetts Charter

(82)Dord North's Penal laws

(ฉ2) Quebec Act 
Persons Mentioned by the Authors:

British
(1) George III
(11) General Gage
(2) Lord Bute
(12) Lord Howe
(3)W1lliam P1tt
(13) Lord Cornwallis
(4) George Grenville
(14) John Burgoyne
(5) Charles Townshend
(15) Henry Clinton
(6) Colonel Barro
(16) Charles Fox
(7) Edmund Burke
(17) David Hume
(8) George Germain
(18) Catherine Macaulay
(9)Lord North
(19) Dr. Samuel Johns on
(10)Lord Mansfield
(20) Edward Gibbon
Amerlcans and umerican Allies

(1) Bonjamin Franklin

(2) Patrick Henry

(3) James Otis

(4) Jorm Adams

(5) Samuel Adams

(6) Joslah Quincy

(7) Alexander Hamilt on

(8) Gouverneur Morris

(9) George Washington

(10) Thomas Paine

(11)Christopher Gadsden
(13) Thomes Jefferson

(14) Mrs. John Adams

(15) Mrs. Henry Corbin

(16) Joseph Galloway

(17) General Robertson

(18) Benedict Arnold

(19) General Montgomery

(20) John Witherspoon

(21) Philip Freneau

(22) George Rogers Clark

(23) Generaj Gates

(12) ? Wythe of Virginia (24) General Greene 
(25) Francis Marion

(26) Thoman Sumter

(27) Andrew Pickens

(28) John Paul Jones

(29) John Barry

(30) Charles Leo

(3I) Daniel Morgan

(32) John Sullivan

(33) Anthony Wayno

(34) Bar on v on Steuben

(35) Marquis de Lafayotte

(36) Baron de Kalb

(37) Casimir Pulask1

(38) Thaddeus Kosc1usko
(39) Mrs.Elizabeth Timotheo

(40) Mrs.Mercy Warren

(41) Mrs.John Adams

(42) Martha Washington

(43) Mrs.Sarah Bacho

(44) Hayn Solomon

(45) James Madison

(46) James Monroe

(47) Robert Morris

(48) Silas Deane

(49) Arthur Lee

(50) John Jay

(51) General Schuyler

Events of the Nar Ment1oned by the Authors:

(1) Battie of Lexington

(2) Battle of Concord

(3) Battle of Bunker H1ll

(4) Evacuation of Boston by the British

(5) Invasion of Canada

(6) Battle of Brooklyn Helghts, Harlem and white Plains

(7) Battle of Trenton

(8) Battle of Princeton

(9) Occupation of Philadelphia by the British (10)Battle of Saratoga 
(11) Eracuation of Philadelphia by the British

(12) Battio of Monmouth

(13) Capture of Kaskaskia

(14) Capture of Vincennes

(15) Capture of Savannah, Ga..

(16) Capture of Charleston, S.C.

(17) Battle of Camden

(18) Battle of Cowpens

(19) Battle of King's Mountain

(20) Battle of Guildford Court House

(21) Surrender at Yorktown

(22) Battle of Brandywine

(23) Battle of Bennington

(24) Battle of Germentown

The Most Important Event of the War in the Opinion of the Authors:

(1) Battle of Saratoga

Results of the War Mentioned by the Authors:

(I) England recognized the Independence of the thirteon American colonies.

(2) The Mississ ipp I River was fixed as the westem boundary of the United States.

(3) Florida was ceded to Spain. 
Beard and Beard'd History of the United States gives about 20,757 words or about $8.1 \%$ of the space of the entire book to the American Revolution of 1776. The book, with 1ts good paper, large print, fourteen black and white 1llustrations and two colored in that part deroted to the American Revolution makes a striking appeal for further investigation. 
X- History of the United States --by Emerson David Fite

Henry Holt and Co.,

New York, 1916.

Concerning the American Revolution, Mr. Fite states:

The Effect on the British of Their V1ctory in the Seven Years

War

In the early days of the seventeenth century

it was a great experiment in the world's history

for one nation to attempt to build up and govern

a frontier in the wilderness thousands of miles

away and separated from the home country by a

vast ocean. The British had gone into the exper-

iment and had on the whole succeoded admirably,

as their prosperous and rapidly growing colonies

of the olghteenth century proved. Then going

blindly in the face of this acknowledged success,

they adopted an entirely different policy and

lost thirteen of their most promising colonies. (p.117).

The New Colonial Policy

Lot it be remembered that Great Britain did not alm her new legislation at the 'thirteen colonies.' Had anyone at the time spoken of the 'thirteen colonies', the expression would have conveyed no meaning, for no one would have known which thirteen colonies were meant. Great Britain had more than twenty colonies in and har new pollcy applied to them all, to Jamaica and Barbados as well as to Massachusetts and virginia. (p.117).

\section{The Sugar Act}

The amount of revenue[from the Bugar Act] was not materially increased, whilst an undesirable spirit of resentment against the mother country was aroused, especially in commercial New England. (p.118).

The Stamp Act

The promise was given to the colonies by the 
British government that the first revenue secured foom the sale of the stamps rould be expended for the immediate purpose of putting dow the conspiracy of Pontiac, an uprising of the Indians west of the Alleghanies, and that under no circumstances would any portion of the money be expended outside of America.

Massachusetts had levied such a tax [Stamp tax] upon herself in 1755, Great Britain collected such a tax at home, and taxes of the same nature are now collected in the United Stetes;but the Americans of 1765 flatly refused to have anything to do with a tax imposed on them by the British. (p.119).

\section{Constitutional Arguments}

No one at all conversant with English history could deny that one of the dearest rights of Engl1shmen was to vote their own taxes.... It was their undoubted right as Englishmen, the imericans claimed, to have a volce in the imposition of such taxes [internal taxes] and without their consent the taxes would be vold.

It was sheer nonsense to hold up to the Americans in the crisis the British theory that every member of the House of Commons represented in that body every subject in the kingdom and that consequently the Americans, as members of the British empire, were represented in the Parliament in London. The British and the Amerlcan views of representation were quite different, and fust here was a source of misunderstending. (p.120).

\section{British and American Views of Representation}

The Americans, knowing that they elected no representative to the British Parliament and that none left their shores to attend the meetings of that body, could well claim, from their point of view, that they were unrepresented in the law-making body in London.... In justification of the British taxation of America, was the course of spain, which derived large revenues from her American possessions..... France also imposed taxes on her American possessions.(p.121). 
The Arbitrary Course of George III

George III was English in his oducation, a man of tremendous will power and energy, though not of great intellectual ability. (p.i22).

The Townshend Acts

It [Townshend Acts] was more than a regulation of commerce; it was a revenue measure, the Income from which was to be used to pay the salaries of the colonial judges and governors. (p.122).

The Trial of the Boston Massacre Soldiers

The efforts of two prominent colonial lawyers, John Adams and Josiah Quincy, in bohalf of the accused[English soldiers who fired the shots in the Boston Massacre, and the conservative verdict of the jury were evidence that the Amer1 cans were as a whole falr-minded and not bioadthirsty . (p.124).

The 'Pariff on Tea

In fact, tea could be bought more cheaply in America than in England;but the principle of taxation without representation was involved, and on this point the Americans would not yield. (p.125).

The Intolerable and Quebec Acts

The rapid succession of events could have but one meaning, the mother country and her colonies did not understand one another. A crisis was at hand. (p.126).

The Loyalty of the Continental Congress

The First Continental Congress of 1774 was outwardiy a loyal body with no revolutionary tendencles apperent, but it nevertheless strenuously objected to the late 'tyrannical acts' of Great Britain. (p.127).

Criticism of British Generals

Both General Gage and General Howe who suc- 
coeded $\mathrm{h}$ in in command of the British before the city [Boston] was evacuated, were severelycritlcized for their 'nogligence' 'and 'delay' during the previous winter, when the woak $A_{m e r-}$ lcan Iines might have been broken through at almost any time. (p.131).

\section{The British Proclamation of 1763}

The real object of the proclamation [of 1763 ] was as much to check the expansion of the colonies and render them more easy of British control, as 1t was to safeguard the welfare of the Indians and reconcile them to their new masters;but it avalled nothing. The frontiersmen would not brook the unjust restrictions. $(p .133)$.

Evidences of Growing Independence

As a result of the fighting that had arready taken place, of the assumption of national powers by the Continental Congress, of the revolutionary formation of new state governments that had already begun, and of the implacable and exasperating attitude of the mother country, the tide of public opinion was setting in $f$ ast in favor of independence. (p.138).

Americans Not Opposed to British Sovereignty

The Americans, who opposed the writs of assistance, the stamp tax, the Townshend Acts, and the 'Intolerable Acts of 1774, were avowodly loyal subjects of King George III. They were opposing the government of the day, to be sure, but not the soverelgnty of the British Empire. (p.138).

Criticlsm of General Howe

General Howe was severely criticized for allowing Washington to escape from here [New York City] for with the superior British forces he should have been able to commend both the land and water routes of the American retreat. (p.143). 
Taxation of Colonies Act

The Taxation of the Colonies Act of 1778, which still governs Great Britain's relations with her colonies in this matter, provided that Parliament 'will not impose any duty, tax or assessment whatever, payable in any of His Majesty's colonies, provinces and plantations in North America or the West Indies;except only such duties as it may be expedient to impose for the regulation of commerce; the net produce of which duties to be alway.s paid and applied to and for the use of the colony, province, or plantation in which the same shall be respectively levied, in such manner as other duties collected by the authority of the respective general courts, or general assemblies of such colonies, provinces or plantations, are ordinarily paid and applied.' (pp.148-150).

Folly of Cornwallis

Cornwallis settled down at Yorktown,Virginia, in just such a foolish situation as that taken by the Americans at Breed's Hill at the outset of the war. (p.159).

Why Amertca Won the War

Green's masterly campaign in the Carolinas, Washington's equally wonderful movement from New York and the timely aid of the French had saved the day. (p.159).

George III at Fault

In making military appointwents, in working out the detalis of military operations, and in the general conduct of the war, he [Goorge III] had directed the polley of the government, his ministers serving merely as his agents. Even the Prime Minister, Lord North... was at heart opposed to the war.....After the surrender of Burgoyne, the nation turned to P1tt, the savior of the country in the crisis of the Seven Years: War, and demanded his appointment as Prime Minister, but the King refused. 'This episode,' says Lecky, 'appears to me to be the most criminal in the whole reign of George III.' Whon the surrender of Cornwallis became known in Great Britain, the people could see nothing 
but the decline of the British Empire, and were plunged into the deepest gloom.... In obedience to the will of his angered subjects the King at last allowed North to resign, in March 1782. The Whig Prime Minister to succeed him was Lord Rockingham.... This was the end of royal control of the British cabinet.From that day to this, no monarch has dared to keep in office ministers who do not possess the confidence of the people. The loss of her American colonies, therefore, profoundly influenced the form of the British government. (p.161).

Evaluation:

In writing his history, Mr. Fite claims that the American Revolution of 1776 came about through misunderstanding on the part of both the colonies and the mother country. In his analysis of the causes which led to the final break, he has been reasonably fair to both sides and has tried to give both sides of the various questions. For Instance, in justification of Great Britain, he says that "Great Britain had more than twenty colonies In America and her new policy applied to them all." Furthermore, Great Britain promised her colonies that no portion of the money raised from the revenue acts "would be expended outside of America." He calls attention to the fact that stamp taxes were nothing new. "Massachusetts," he says, "had levied such a tax on herself in 1755, Great Britain collected such a tax at home, and taxes of the same nature are now collected in the United States." The objection ralsed by the Americans was due to their bellef that Great Britain had no right to tax them since they 
were unrepresented in the British Parliament. "Here," says Mr. Fite, "was a source of misunderstanding" as the Brit1sh and American "views of representation were quite different." However "In justification of the British taxation of America, was the course of Spain" and also of France who collected revenues from their American possessions. In other words, it was customary to derive revenues from one's colonies.

In defense of the colonies, he states that since they claimed they were unrepresented in the English Parliament they were defending "one of the dearest rights of Englishmen", the right to rote their own taxes. In regard to the tea tax, the Amerlcans belleved that" the principle of taxation without representation was involved, and on this point the Americans would not jield."

He shows various reasons why the colonists were indignant. The Townshend Acts were a"revenue measure", the Proclamation Act of 1763 was almed at checking "the expansion of the colonies"and at rendering them "more easy of British control", and the attitude of the mother coumtry was "Implacable" and "exasperating." So Britain went "blindly in the face" of her success of emplre-buildIng and lost "thirteen of her most promising colonies." In all this trouble, the blame for England's stand is laid upon George III who "directed the policy of the government, his ministers serving merely as his agents." 
"The First Continental Congress was outwardiy a loyal body with no revolutionary tendences apparent" and the Americans "were opposing the government of the day, to be sure, but not the sovereignty of the British Empire." As a whole they were "fair-minded and not bloodthirsty" and hoped that a way would be found whereby they could remain English subjects and yet be allowed to levy their own taxes.

The whole trouble, in Mr. Fite's opinion, was that the "mother country and her colonies did not understand one another." However, the loss of the thirteen American colonies taught Great Britain much. The Taxation of the Colonies Act of 1778, which Great Britain offered to the American colonies in the hope of reconciling them, "still governs Great Britain's relations with her colonies "In the matter of taxation. Also because of George III's actions in persisting in waging war on the American colonies in opposition to Lord North and most of his ministers, "the end of royal control of the British cabinet" came about.

In regard to Britain's loss of the war, Mr. Fite claims this was due to "negligence" and "delay" on the part of Gage,Howe and others, to"Greene's masterly campaigns in the Carolinas, Washington's equally wonderful movement from New York, the timely ald of the French" and to the "foolish situation" in which Cornwallis settled 
down at Yorktown.

Much space in Mr. Fite's book is devoted to the various campalgns and American Congresses and to the exploits of numerous American heroes. 
Causes of the War Mentioned by Mr: Fite:

(I) Navigation Acts

(2) Writs of Assistance

(3) Smuggling

(4) Molasses Act

(5) Sugar Act

(6) Stamp Act

(7) Taxation without representation

(8) Declaratory Act

(9) Townshend Acts

(10)Quartering Act

(II)Boston Massacre

(12)Burning of the Gaspee

(13)Boston Tea Party

(14)Boston Port B111

(15) Massachusetts Government Act

(16)Administration of Justice Act

(17) Quebec Act

(18) Proclamation of 1763

Persons Mentioned by the Author:

British

(1) George Grenville

(5)Lord North

(2) William P1tt

(6)General Gage

(3) Goorge III

(7)Major Pitcairn

(4) Charles Townshend

(8) General Howe 
(9) Henry clinton

(10) Lord Cormwallis

(11) ? Parker

(12)Governor Dunmore of Va.

(13) Edmund Burke

(14)Colonel st.Leger

(15)General Burgoyne
(16)Colonel Hamilton

(17) John Andre

(18)Major Fergus on

(19)? Tarleton

(20)Admiral Rodney

(21) Lord Rockingham

(22) Lord Shelburne

\section{Americans and American Allies}

(I) Jomes Ot1s

(2) John Dickinson

(3) Samuel Adoms

(4) John Adams

(5) Josiah Quincy

(6) Richard Henry Leo

(7) Patrick Henry

(8) George Washington

(9) Paul Revere

(10)Captain Parker

(II) Israel Putnam

(12) John Hancock

(13)Bonedict Amold

(14) John Stark

(15)Ethan Allen

(16) Seth Warner

(17)William Prescott
(18) Dr. Joseph Warren

(19)General Montgomery

(20)Colonel Moultrie

(21) John Sevier

(22) James Roberts on

(23) Daniel Boone

(24) John Jay

(25)Benjamin Franklin

(26) Thomas Jefferson

(27)Richard Penn

(28) Thomes Paine

(29) Roger Sherman

(30) Robert Livingston

(3I) Charles Lee

(32) Robert Morr1s

(33)General Herkimer

(34) General Schuyler 
(35) General Gates

(36) Marquis de Lafayette

(37) Johann De Kalb

(38) Baron von Steuben

(39) Thaddeus Kosc1usko

(40) Casimir Pulaski

(41) Count d'Estaing

(42) Anthony Wayne

(43) General Sullivan

(44) George Rogers Clark

(45) John Baul Jones

(46) ? Paulding

(47) ? W1lliams

(48) ? Van Wert
(49) Nathan Halo

(50) General Lincoln

(51) Andrew Plckens

(52) Francis Marion

(53) Thomas Sumter

(54) Nathanael Greene

(55) General Morgan

(56) Admiral de Grasso

(57) Count Rochambeau

(58) Henry Laurens

(59) Joseph Galloway

Events of the War Mentioned by the Author:

(I) Battle of Lexington

(2) Battle of Concord

(3) Capture of Ticonderoga

(4) Capture of Crown Point

(5) Battle of Bunker Hill

(6) Invasion of Canada

(7) Evacuation of Boston by the British

(8) Burning of Norfolk

(9) Battle of Brooklyn Heights

(10)Battle of Trenton 
(11)Battle of Princeton

(12)Battle of Brandywine

(13) Battle of Germantown

(14) Occupation of Philadelphia by the British

(15)Battle of Oriskany

(16)Battle of Bennington

(17) Battle of Saratoga

(18)Evacuation of Philadelphia by the British

(19)Battle of Monmouth

(20) Capture of Stony Point

(21)Battle against the Indians in Western N.Y.

(22) Capture of vincennes

(23) Capture of the Serapis

(24)Capture of Savannah

(25) Capture of Charleston

(26) Battle of Camden

(27)Battle of King's Mountain

(28)Battle of Cowpens

(29) Battle of Guildford Court House

(30) Surrender at Yorktown

The Most Important Event of the War in the Opinion of the Author:

(1) Battle of Saratoga 
Results of the War as Seen by Mr. Fite:

(1) England recognized the independence of the thirteen American colonies.

(2) Certain fishing rights off the Newfoundland cost were given to the Americans.

(3) Both nations were to have the right to navigate the Mississippi River.

(4) The United States was not to hamper the English merchants in collecting the debts owed them by Americans.

(5) The Mississippi River was made the western boundary of the United States.

(6) Florida was given to spain.

(7) The royal control of the British cabinet was ended. "From that day to this, no monarch has dared to keep in office ministers who do not possess the confidence of the people."

(8) Taxation of the Colonies Act of 1778 is still used by Great Britain in hor relations with her colonies.

Fite's History of the United States devotes about 20,790 words or9.2\% of 1ts entire space to the American Revolution of 1776. It contains thirteen black and white 1llustrations, ten maps, a few of which are in color and 
no graphs in that part given over to the American Revolution. The print is fair and the paper,good but the book, copyrighted in 1916, presents rather an obsolete appearance and fa1ls to invite one to further acquaintance. 


\section{COMPARISONS}

In the following comparisons, the Roman numerals refer to those given the books when they were analyzed.

I- refers to Warmer and Marten's Groundwork of British History.

II-refers to Mowat's A New History of Great Britain.

III- refers to Muir's British History.

IV- refers to Rayner's A Concise History of Britain.

V- refers to Somervell's A Conclse History of Great Britain.

VI- refers to Barker, Dodd and Commager's Our Nation's Development.

VII-refors to Faulkner and Kepner's Amer1ca: Its History and People.

VIII-refers to Muzzey's H1story of the American People.

IX- refers to Beard and Beard's History of the United States.

X- refers to Fite's History of the United States.

The first five of these books are those used in the secondary schools of England and the last five are those used in the secondery schools of the United States of Amer 1ce.

In making the comparisons between the ten books, if the Item compared was mentioned in a book, the number of 
the book has been listed $\ldots-$ in the British column, if a British book and in the American column if an American book. If the 1tem was not mentioned in a book, the book's number was omitted.

\section{CAUSES OF THE WAR}

BRITISH BOOKS

AMERIOAN BOOKS TOTAL

(a) Trade Restrictions

I, $\mathrm{V} \quad$ VIII, IX, 4

(b) Manufacturing Restrictions

I, II, V VII,

(c) Navigation Acts

I, II, IV, $\mathrm{V} \|$ VII, VIII, IX, $\mathrm{X} \| 8$

(d) Smuggling

I, III, IV, V VII, VIII, IX, $x \| 8$

(e) Establishment of a standing army In Americe

I, V VII, VIII,

(f) Stamp Act

I, II, III, IV, V $\|$ VI, VII, VIII, IX, $\mathrm{X} \| 10$ (g) Taxation without representation

I, II, III, IV, V VI, VII, VIII, IX, $x \| 10$ (h) Townshend Acts

I, IV, VI, VII, VIII, IX, $x \| 7$

(1) Boston Massacre

I, II, III, IV, V

VI, VII, VIII, IX, XXI0 
(j) Bostan Tea Party

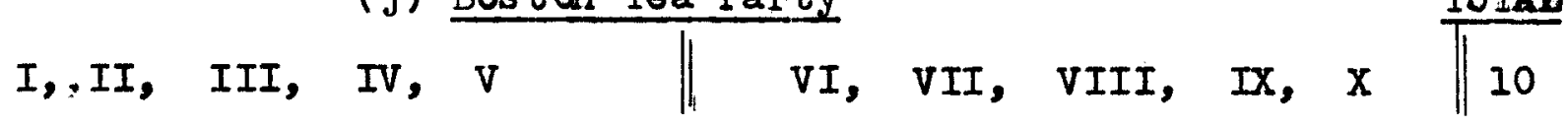

(k) Burning of the Gaspee

I, II,

VI,

VIII, IX, X $\quad 6$

(1) Closing of the Port of Boston

$I$, II, IV, V $\|$ VI, VII, VIII, IX, X $\| 9$

(m) Suspension of the Massachusetts Charter

$I$, II, III, IV, V $\quad$ VI, VII, VIII, IX, X 10

(n) Molasses Act

III,

VI, VII, VIII, IX, X 6

(o) Declaratory Act

III,

VI, VII, VIII, IX, X

(p) Quebec Act

I, III,

VII, VIII, IX, $\mathrm{X} \| 6$

(q) Lord North's Penal Lars

III, V

VII,

IX,

4

(r) Removal of the French Menace

III, $\mathrm{V} \quad \mathrm{VI}$,

(s) Governmental System

III, IV, V

(t) Proclamation of 1763

III,

vII, VIII, IX, $\mathrm{X}$

(u) Townshend's Penal Laws

VI, 
(v) Administration of Justice Act<smiles>[141In]C1=CC=C1</smiles>
TOTAL

$\mathrm{x} \quad \| 2$

(w) Sugar Act

VI, VII, VIII, IX, $X \quad \| 5$

(x) Writs of Assistance

VI, VII, VIII, IX, X

(y) Quartering Act

$\|\quad \mathrm{VII}, \quad \mathrm{IX}, \quad\| 2$

(z) Closing of New York's Assembly

$\|$ IX $\quad \| 1$

(a') Lexington of the South

If IX

$\| 1$

(b') Grenvilie's Restriction of Paper Money Act

$\|$

IX

$\| 1$

(c') Old Colonial Systers

IV

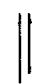

1

(d') The Mercantile System

IV, V

$\|$ 
BRITISH BOOKS

\section{AMERICAN BOOKS}

(a) George Grenville

I, II, III, IV, V VII, VIII, IX, $\mathrm{X} \| 9$

(b) William P1tt

I, II, III, IV, V $\|$ VI, VII, VIII, IX, X $\| 10$ (c) George III

$I, I I, I I I, I V, V \quad V I, V I I, V I I I, I X, X \| 10$
(d) Charles Townshend

I, III, IV, V VI, VII, VIII, IX, $\mathrm{X} \| 10$ (e) Lord North

$I, I I, I I I, I V, V \quad V I, V I I, V I I I, I X, X \| 10$ (f) General Gage

I, III, IV, V $\|$ VI, VII, VIII, IX, X $\| 9$ (g) Major Pitcaim

(h) General Howe

$I, I I, I I I, I V, V \quad V I, V I I, V I I I, I X, X \| 10$ (1) Henry Clinton

I, II, III, IV VII, VIII, IX, X 8

(j) Lord Cornwalis

$I$, II, III, IV, V $\quad$ VI, VII, VIII, IX, X $\| 10$ (k) ? Parker 
(1) Governor Dunmore<smiles>[CH]=C</smiles>

(m) Edmund Burke

I, II, III, IV,

(n) Lord Howe

(0) Cobonel st. Leger
TOTAL

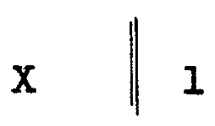

VIII, IX, $X \| 7$

vII, vIII, X $\mid 3$

(p) John Burgoyne

I, II, III, IV, V $\|$ VI, VII, VIII, IX, X $\| 10$ (q) Colonel Hatrilton

(r) John Andre

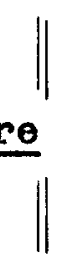
VII, VIII, $\mathrm{X} \quad 3$

(s) Major Ferguson VIII $\mathrm{X} \quad \mid 2$ (t)? Tarleton IV VII,

(u) Admiral Rodney

II, III, IV, V

(v) Lord Rockingham

I, II, III, IV

(w) Lord Shelburne III, VI,

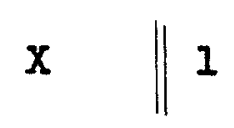

$x \quad|| 3$

$\mathrm{x} \quad \mid 5$

VIII,

$\mathrm{x} \quad \mid 6$

VIII, 


\section{(x) Lord George Germaine}

TOTAL

I, II,

VII; VIII; IX

(y) General Carleton

I, II,

VII, VIII,

(z)

Bolingbroke

II, III,

(a') Lora Bute

II, III,

IX,

(b') Duke of Grafton

II, III,

(c') Lord Rawdon

II,

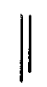

(d') Duke of Newcastle

III,

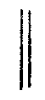

( $0^{\prime}$ ) John Wilkes

III,
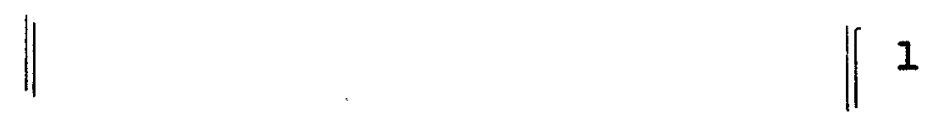

(f') Duke of Bedford

III,

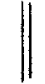

( $\left.g^{\prime}\right)$ Lord Sandw1ch

II I,

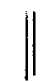

(n') Cha rles Fox

III,

VIII, IX,

(1) ) 1chard Oswald

VI,

VIII, 
(j') S1r Robert Walpole

TOTAL<smiles>[AlH2]</smiles>

(k') Horace Walpole<smiles>[14CH3]</smiles>

(I1) Governor Hutchinson

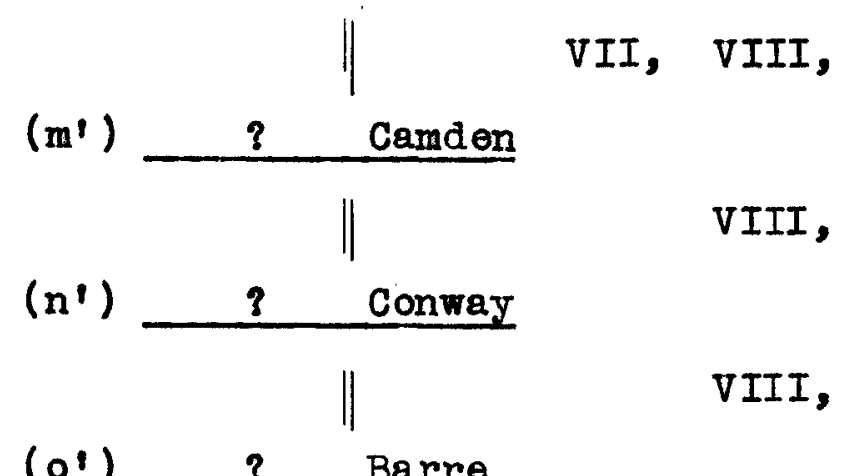

(08)

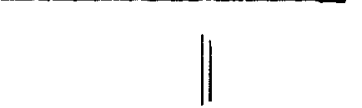

VIII, IX,

(p') Governor Colden

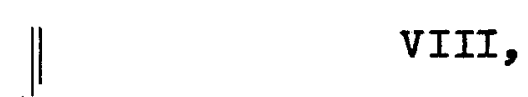

1

(q') Governor Bernard

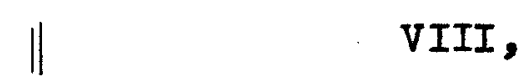

1

(r') Colonel Fergus on

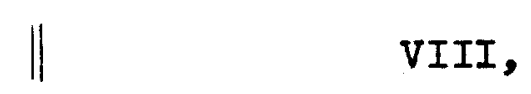

1

(s') ? Phillips

VIII,

$\| 1$

(t') Admiral Graves

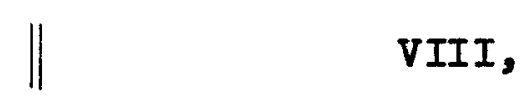

1

(u') Lord Mansfleld 
(v') David Hume

(w') Catherine Macaulay IX, 1

(x') Dr. Samue 1 Johnson<smiles>C=C</smiles>
IX $\| 1$

(y') Edward Gibbon

$\|$

(z') Dean Tucker

v

|| 1

$\left(A^{2}\right)$ Adam Sm1th

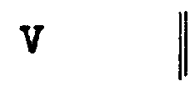

IX, $\| 1$

$V \quad \|$

$\left(B^{2}\right)$ Governor Ell iott

V

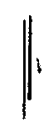

1 
(a) James Ot1s

$\|$ vI, VII, VIII, IX, $X \mid 5$

(b) John Dickinson<smiles>C1=CC=C1</smiles>
VII, VIII, $\mathbf{x} \quad \mid 3$

(c) Samuel Adams IV, $V \quad \|$ VI, VII, VIII, IX, $X \| 7$

(d) John Adams $\|v I, \quad v I I, V I I I, I X, x\| 5$

(e) Josiah Quincy $\mathrm{IX}, \mathrm{X} \| 2$

(f) Richard Henry Loe

VI, VII, VIII, $\quad$ X 4

(g) Patrick Henry

VI, VII, VIII, IX, $\mathrm{X} \| 5$

(h) George Washington

I, II, III, IV, V $\|$ VI, VII, VIII, IX, X 10

(1) Paul Revere

$\|$ VI, VII, VIII, $\quad x \| 4$

(j) John Hancock $\| \quad$ VII, VIII, $\quad \mathrm{x} \| 3$

(k) Captain Parker

VIII,

$\mathrm{x} \| 2$

(1) Israel Putnam

VII, $\mathrm{x} \quad 12$ 
(m) Benediet Arnold

TOTAL

II, III, IV, $\|$ VI, VII, VIII, IX, X $\| 8$

(n) John Stark

(o) Ethan All en

VII, VIII,

$\mathbf{x} \quad \mid \quad 3$

VII, VIII,

$\mathrm{x} \quad \mid 3$

(p) Seth Warner

$x \quad \mid \quad 1$

(q) Colonel William Prescott

VII, VIII,

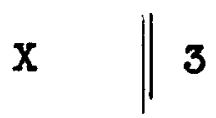

(r) Dr. Joseph Warren

(s) General Montgomery

$x \quad \mid 1$

$$
\text { vI, vII, VIII, IX, } X \| 5
$$

(t) Colonel Moultrie

(u) John Sevier
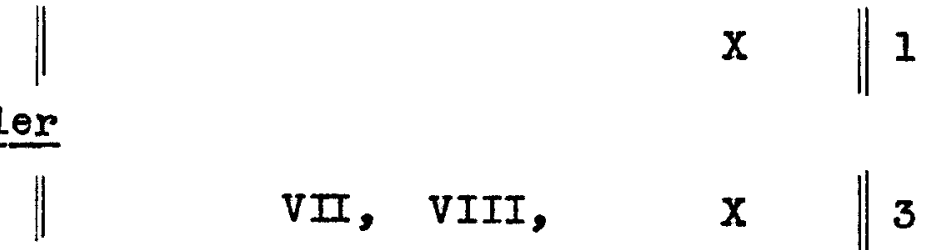

VII, VIII,

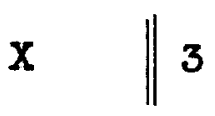

(v) James Robertson

(w) Danfel Boone

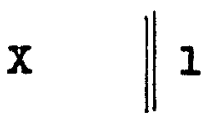

(x) John Jay

VIII,

$\mathrm{X}$

$\| 2$

VI; VII, VIII, IX, X \|5 
(v) Benjamin Franklin

TOTAL III, $\|$ VI, VII, VIII, IX, X $\|_{6}$ (z) Thomas Jefferson $\mathrm{V} \mid \mathrm{VI}, \mathrm{VII}, \mathrm{VIII}, \mathrm{IX}, \mathrm{X}$ 6 (a')Richard Penn $\| \quad \therefore \quad$ X $\quad 1$ (b') Thomas Paine VI, VII, VIII, IX, X (c') Roger Shermen

$$
\text { VI, VII, VIII, X } \| 4
$$

(d') Robert Livingston

$$
\| \text { vI, } \quad x \quad \| 2
$$

(e') Charles Lee

$$
\| \text { VI, VIII, IX, X } \| 4
$$

(f') Robert Morris

$$
\text { VII, IX, } \mathrm{X} \| 3
$$

(g') General Herkimer

$$
\text { VII, VIII, } \mathrm{X} \quad \| 3
$$

(h') Generel Schuyler

II,

$$
\| \quad \text { VII, VIII, IX, } \mathrm{X}
$$

(11) General Gates

I, III, vII, VIII, IX, $\mathrm{X}$ || 6 (ji) Marquis de Lafayette II, VI, VII, VIII, IX, $\mathrm{X}$ 
(K') Johann de Kalb

VI, VII, VIII, IX, X

(1') Baron von Steuben

$\|$ VI, VII, VIII, IX, X

(n') Thaddeus Kosciusko

(n') Casimir Pulaski

VI, VII, VIII, IX, $\mathrm{X} \| 5$

VI, VII, VIII, IX, $\mathrm{X}$

(o') Count d'Estaing<smiles>c1ccccc1</smiles>

VIII,

X

2

(p') Anthony Wayne

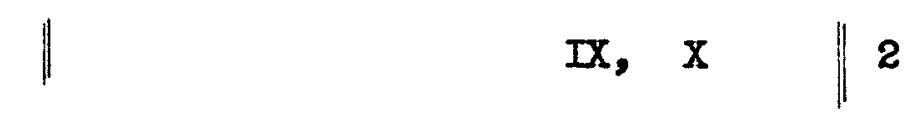

(q') General Sullivan

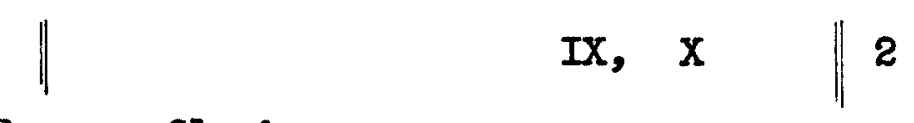

(r') Goorge Rogers Clark

VI, VII, VIII, IX, $\mathrm{X} \| 5$

(s') John Paul Jones

II, vI, VII, VIII, IX, $\mathrm{X}$
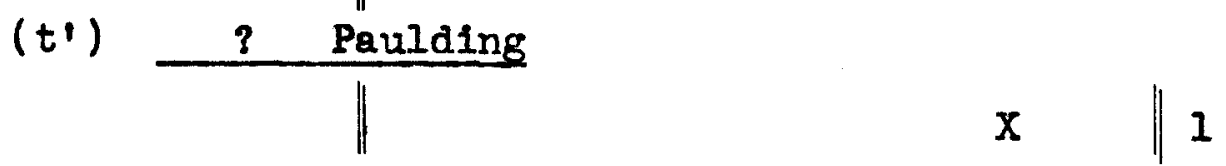

(u') $\frac{? \text { Williams }}{\|}$

$x \quad \| 1$

(v') ? Van Wert

$x \quad \mid 1$

(w') Nathan Hale 
(x') General Lincoln

TOTAL

$\|$ VII, VIII,

(y') Andrew Plckens

VI, VII, VIII, IX, $X \quad \mid 5$

(2') Francis Marion

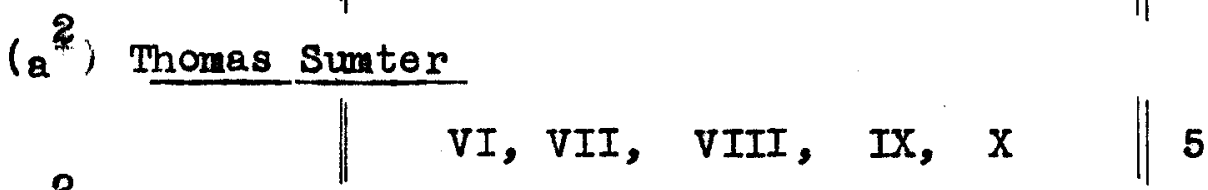

VI, VII, VIII, IX, X 5

$\left(b^{R}\right)$ Nathanael Groene

I,

$\left(c^{2}\right)$ General Morgan

VII, VIII, IX, X $\| 5$

VII, VIII, IX, $\mathrm{X} \| 4$

( $\left.d^{2}\right)$ Admiral de Grasse

II, III, IV,

$\left(\theta^{2}\right)$ Count Rochambeau

III, IV, $V I, V I I, V I I I, \quad X \quad \| 6$

$\left(f^{2}\right)$ Henry Laurens

VI, VII,

$\mathbf{x} \quad \mid 3$

$\left(g^{2}\right)$ Joseph Galloway

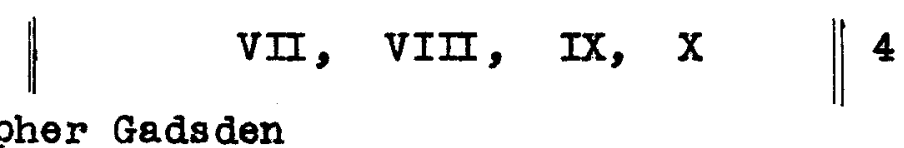

$\left(h^{2}\right)$ Christopher Gadsden

$\left(1^{2}\right)$ John Barry_ VI, VII, IX,

VI, VII, VIII, IX

$\left(j^{2}\right)$ Philip Livingston

VII, VIII, 
$\left(\mathrm{k}^{2}\right)$ the Rutledges

Total
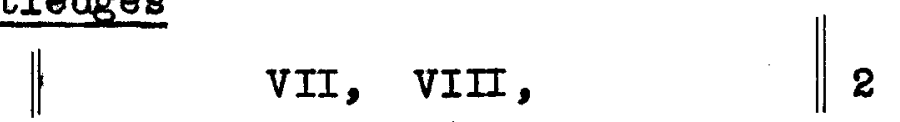

$\left(1^{2}\right)$ William Dawes

2 $\quad$ VII, VIII, $\quad \| 2$

(m) S1las Deane

(n') Hayn Solomon
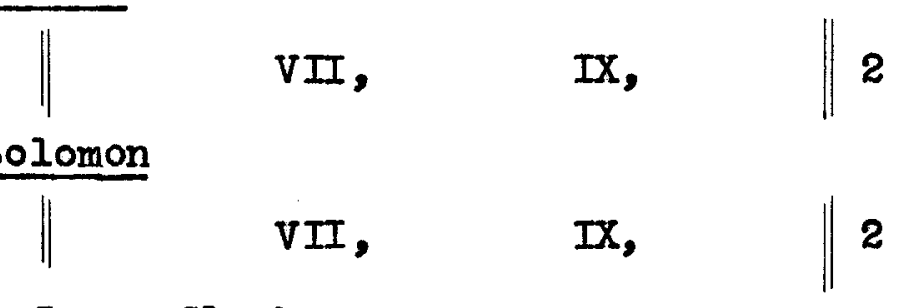

(o2) Parson Jonas Clark
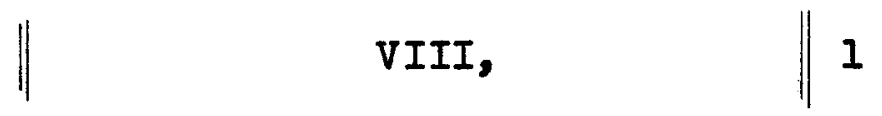

$\left(p^{2}\right)$ ? Ward of Rhode Island

VIII,

$\left(q^{2}\right)$ Edmund Randolph
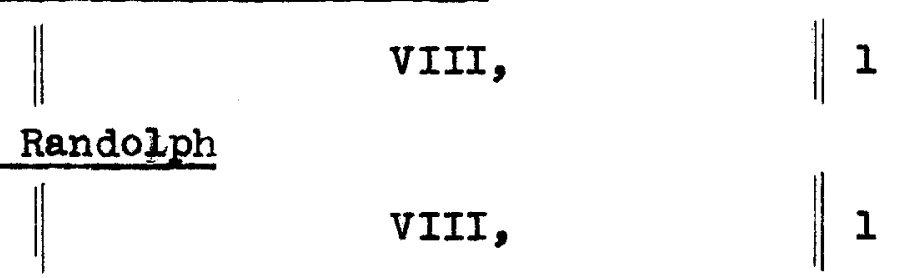

1

( $\left.{ }^{2}\right)$ Alexander Hamilton

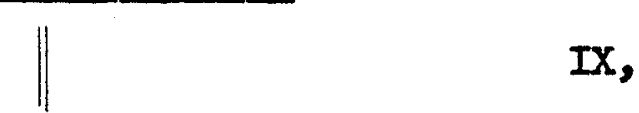

( $\left.{ }^{2}\right)$ Gouvernour Morris

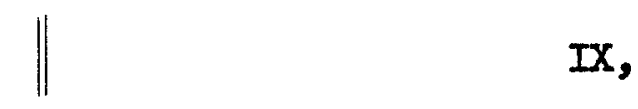

$\left(t^{2}\right)$ ? Wythe of Virginia

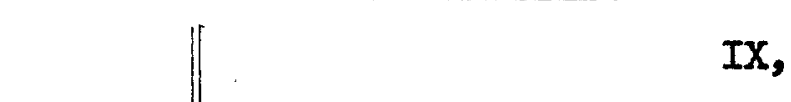

( $\left.u^{2}\right)$ Mrs. John Adams

( $\left.v^{2}\right)$ Mrs. Henry Corbin

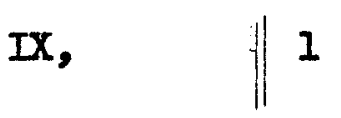

$\left(w^{2}\right)$ General Robertson

IX,

1

IX, 
$\left(x^{2}\right)$ John Witherspoon

TOTAL<smiles>C1=CC=C1</smiles>

IX, 1

$\left(y^{2}\right)$ Ph111p Freneau

IX,

( $\left.z^{2}\right)$ Mrs. Ellzabeth Timothee

$\left(a^{3}\right)$ Mrs. Mercy Warren

IX,

IX,

1

$\left(b^{3}\right)$ Mrs. John Adams

IX,

1

$\left(c^{3}\right)$ Martha Washington

IX,

1

(d $d^{3}$ Mrs. Sarah Bache

$\left(e^{3}\right)$ James Madison

IX,

1

IX,

1

$\left(f^{3}\right)$ James Monroe

IX,

1 
EVENTS OF THE WAR

BRITISH BOOKS

AMERICAN BOOKS

TOTAL

(a) Battle of Lexington

$I, I I, I I I, I V, V \quad V I, V I I, V I I I, I X, x$

(b) Battle of Concord

VI, VII, VIII, IX, $\mathrm{X}$

(c) Capture of Ticonderoge

$\|V I, V I I, V I I I, \quad x \quad\| 4$

(d) Capture of Crown Point

VI, VII,

$\mathbf{x} \quad \| 3$

(e) Battle of Bunker Hill

$I, I I, I I I, I V, V \quad V I, V I I, V I I I, I X, X \| 10$

(f) Invesion of Canada

I, II, III, $\quad$ VI, VII, VIII, IX, X

(g) Evacuation of Boston by the British

I, III, VII, IX, $X$

(h) Burning of Norfolk

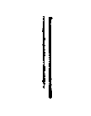

\section{VII,}

$\mathbf{X}$

(1) Battle_of Brooklyn Helghts

$$
\text { VI, VII, VIII, IX, } X \quad \| 5
$$

(j) Battle of Trenton

I, II, III, VI, VII, VIII, IX, X $\| 8$

(k) Battle of Princeton VI, VII, VIII, IX, X 5

(1) Battle of Brandywine

I, III, IV, V VI, VII, VIII, IX, $X$ 
(m) Battle of Germantown III, VI, VII, VIII, IX, $\mathrm{X}$

(n) Occupation of Philadelphia by the British $I, I I, \quad I I I, I V, V \quad V I, V I I, V I I I, I X, X \| 10$ (o) Battle of Orlskany $\|$ VII, VIII, $\quad x \quad \| 3$

(p) Battle of Bennington VII, VIII, IX, $\mathrm{X} \| 4$

(q) Battle of Saratoga

$I, I I, I I I, I V, V \quad V I, V I I, V I I I, I X, X \| 10$ (r) Evacuation of Philadelphia by British

I, III, VII, VIII, IX, X $\| 6$

(s) Battle of Monmouth

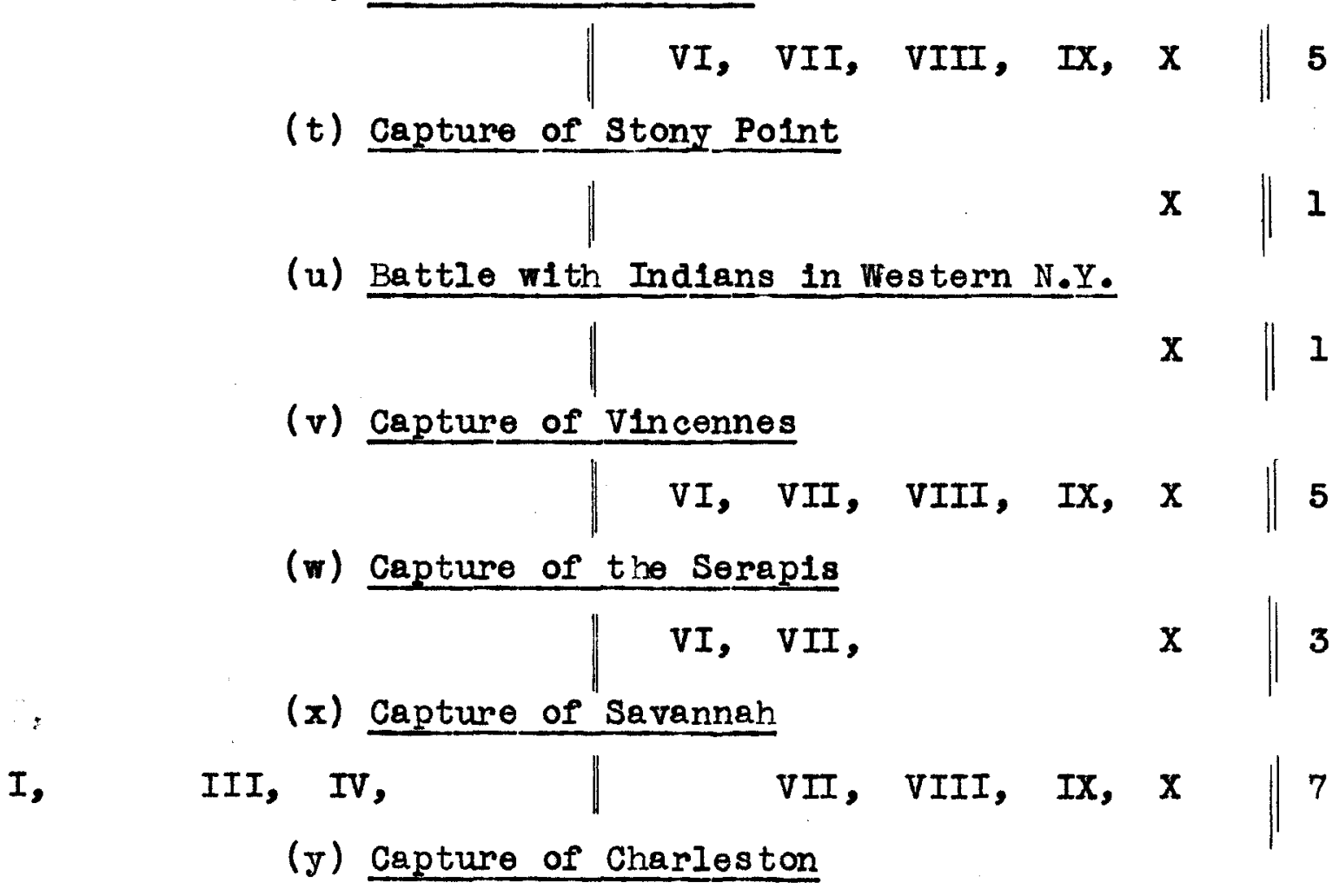

I, II, III, IV,

VII, VIII, IX, $\mathrm{X}$ 8 
(z) Battle of Camden

TOTAL

$I$, II, III, $\|$ VI, VII, VIII, IX, $X \| 8$

(a') Battle of King's Mountain

VI, VII, VIII, IX, $X \quad \mid 5$

(b') Battle of Compens

$\| V I, \quad I X, X$

3

(c') Battle of Guilaford Court House

I, II, III, $\| \mathrm{VI}, \quad$ IX, $X \| 6$

(d') Surrender at Yorktown

$I$, II, III, IV, V $\|$ VI, VII, VIII, IX, $X \| 10$

(a') Occupation of New York

I, III, IV, $\mathrm{V}$

4

(f') Attempt of British to Seize Charleston

III,

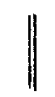

1

( $\left.g^{\prime}\right)$ Gapture of Kaskaskia

$\| V I, \cdot V I I, V I I I, I X$,

(h') Burning of Falmouth Harbor

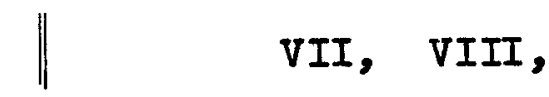

2

(1') Cepture of Cahokia

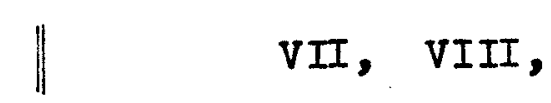

2

THE MOST IMPORTANT EVENT OF THE WAR

BRITISH BOOKS

AMERICAN BOOKS

(a) Battle of Saratoga

I, II, III, IV, V $\|$ VI, VII, VIII, IX, X $\| 10$ 
RESULTS OF THE WAR

BRITISH BOOKS

AMERICAN BOOKS

TOTAT

(a) The independence of the United States was recognized. $I$, II, III, IV, V $\|$ VI, VII, VIII, IX, X

(b) The foundations of another empire (Canada) are strengthened. I,

(c) Florida is ceded to Spain.

I, II, III, $\quad \mathbf{v}$

(d) The moderm, self-governing British Empire was devoloped. II,

(e) The American Revolution made the French Revolution inevitable, III,

(f) The boundaries of the United States were defined. V | VI, VII, VIII, IX, $\mathrm{X}$

(g) Both Fngland and the United States secured the right to navigate the Miss 1ss1pp1.

VI, VII, VIII,

(h) The United States secured flshing rights off Newfoundland.

$$
\|V I, V I I, V I I I, \quad x \quad\| 4
$$

(1) The United States agreed not to hamper Engl1sh merchants In collecting debts owed by the Americans.

VI, VII, VIII,

$\mathrm{X}$

(j) English troops were to be removed from the Enited States.

$$
\mathrm{VI} \text {, }
$$

(k) No provision was made for comercial relations between England and the united States.

$$
\| v I \text {, }
$$


(1) Manufacturing was begun in the United States.

VII, VIII,

(m) The governing class of aristocrats was roplacod by a new group of people in the United states.<smiles>[14CH2][14CH2][14CH3]</smiles>

(n) Bills of Rights were included in the new state constituElons of the United states.

(o) Certain laws, such as those of primogeniture and of enta11, were abolished in the United states.

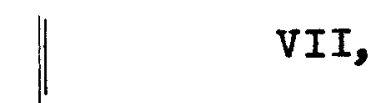

(p) The United States was practically bankrupt.

VIII,

(q) The royal control of the British cabinet was ended.<smiles>C=C</smiles>

$\mathrm{X}$

(r) The Taxation of the Colonies Act of 1778 has been used by England ever since.<smiles>C=C</smiles>

$\mathrm{x}$

(s) France secured certain small 1slands.

I, II, III,

V 
CHAPTER IV

SUMMARY AND CONCLUSIONS 
CHAPTER IV

SUMMARY AND CONCLUSIONS

Thesis: The purpose of this study was to compare the treatment of the American Revolution of 1776 in some currently used secondary school history textbooks of Fingland with some of those used currently in the secondary schools of the United States.

Inferences: The writer found it necessary to make several inferences. First, the writer inferred that the ten books used in this study are today in use in the secondary schools of the respective countries; second, that the books examined are typical of the history textbooks in use in the secondary schools of the respective countries; third, that the number of books used is sufficient to warrant significant conclusions; fourth, that the evaluation of the books has been objective, in so far as that is possible; and fifth, that a fair basis of comparison has been used.

\section{Conclusions:}

1. The American books devote more space to the American Revolution of 1776 than do the British books.

2. The American books are edited in a more attractive fashIon -with pictures and maps--than are the British books.

3. The books differ greatly in the causes, events, results, and persons discussed.

4. No British book is Pro-British. 
5. Two American books are Pro-American.

6. The British books present a rather noutral viewpolnt.

7. The newer American books present a rather neutral viewpoint.

8. The British books elther place the entire blame for the the war on Great Britain or on the misunderstanding existing between Great Britain and the thirteon colonies.

9. The older Ame rican books place the blame for the war on Great Britain, while the newer books present the facts and allow the reader to form his own judgment.

10. The American books give much space to the stamp Act Congress and the First and Second Continentel Congresses.

11. The British books either do not mention these Congresses or else simply mention them in pessing.

12. The American books treat the American Revolution of 1776 as an event of momentous importance.

13. The British books treat the American Revolution of 1776 as a mere incident in Britain's history. 14. The American books are written in such a way as to inspire respect and veneration for one's forbears.

15. The British books are not written with a desire to inspire respect and veneration for one's forbears.

16. American books mention more causes of the war than do British books.

17. Some American book mentions the majority of the causes mentioned in the British books a 
18. Some British book mentions the majority of the causes mentioned in the American books.

19. Four causes --the Stamp Act, Boston Massacre, Boston Tea Party and the suspension of the Massachusetts' Charter-are mentioned in all the American as well as in all the British books.

20. "Taxation without Representation" is referred to in all the American and in all the British books as a cause of the war.

21. Some British books mention the Declaration of Independence. 22. All American books mention the Declaration of Independence. 23. American books mention more events of the war than do the British books.

24.F1ve events of the war --the occupation of Philadelphia, the Battle of Lexington, the Battle of Bunker H1ll, the Battle of Saratoga and the Surrender at Yorktom-- are mentioned in all the American and in all the British books. 25. The Battle of Saratoga is mentioned as the most important event of the war in all the American and in all the British books.

26. The American books mention more persons than do the British books.

27. George Washington is the only American mentioned in all the American and in all the British books. 
28.Six British persons --W11liam Pitt, George III, Lord North, General Howe, Lord Cornwallis and General Burgoyme-- are mentioned in all the American and in all the British books.

29.All the books --Amerlcan and British-- give some results of the war.

30. The American books tend to give the results of importance to America.

31. The British books tend to give the results of importance to Great Britain.

32. One American book mentions two results of great 1mportance to the British Empire today.

33.All American and all British books mention as a result of the war the independence of the thirteen American colonies.

\section{Criteria for Teachers:}

This study can be seen to have certain implications for teachers. The history textbooks used in the secondary schools of England and of the United States of America have been found to vary in their treatment of the American Revolution of 1776. The American books do more to foster hero worship of one's forbears than do the Engliah books. And in this there is a certain danger. The English books are found to give a fairer presentation of the war than do the American 
books. What should the American teachers do about this? Probably it would be well for every teacher of history in the schools of the United States, when teaching a controversial subject, to check himself by the following criteria which have been suggested by this study.

1. Good teaching is not satisfled with presenting only that information contained in one textbook.

2. Good teaching makes use of many reference books.

3. Good teaching presents the vlewpoint of as many authors as possible.

4. Good teaching aids the pupils to determine what is the probable truth after a consideration of many viewpoints. 5. Good teaching aims to make the pupils well informed on a subject before they attempt to form an opinion.

6. Good teaching aims to develop puplls who are open-minded. 7. Good teaching does not tolerate pupils who are one-sided.

8. Good teaching does not compel pupils to accept certain Ideas and attitudes.

9. Good teaching allows pupils to form their own ldeas and attitudes provided they are logically sound.

10.Good teaching honestly tries to present all sides of a controversial subject.

11.Good teaching does not spread propaganda. 12.Good teaching tries to offset all propaganda by teaching the facts in so far as they can be known. 
13. Good teaching leads pupils to love their native land, to glory in her good deeds and to desplse her evil deeds.

14. Good teaching teaches intelligent loyalty to one's country •

15. Good teaching teaches pupils to hate the greed and duplicity of any country --their own as well as another.

16. Good teaching tries to develop an international outlook in pupils.

17. Good teaching finds the teacher acting merely as a guide when teaching controversial subjects.

18. Good teaching finds the teacher so teaching a controversial subject that his pupils cannot tell what are his beliefs on the subject.

If a teacher finds that he rates high according to these criteria, he may count himself a good teacher. 
BIBLIOGRAPHY 


\section{BIBLIOGRAPHY}

\section{BOOKS}

Barker, Eugene C., and William E. Dodd and Henry Steele Commager. Our Nation's Development. Evanston, Ill.: Row, Peterson and Co.,1934.

Beard,Charles and Mary R. Beard. History of the United States. Now York:MacMillan Co., 1929.

Faulkner, Harold Underwood and Tyler Kepner. America: Its History and People. New York: Harper and Brothers,I934.

F1te, Ferson David. His tory of the United States. New York: Henry Holt and Co.,1916.

Mowat,R.B. A New History of Great Britain. London, Oxford University Press, 1923.

Muir, Ramsey. British History • Yonkers-on-Huds on, N.Y.: Worla Book Co., 1930 .

Muzzey, David Saville. History of the American People. Boston; ifinn and co.,1929.

Rayner, Robert M. A Concise History of Britain. London: Longmans, Green and Co.,1937.

Russell, Bertrand. Why Men F1ght. New York: Century, 1916.

Somervell,D.C. A Concise History of Great Britain. London: G. Bell and Sons. 1934 .

Warner, George Townsend and C.K.H. Marten. The Groundwork of British History. London: Blackie and Son, 1923.

\section{PAMPHLETS}

Keescker, Ward W. Leg1slation concerning free textbooks. Pamphlet No.59.U.S. Department of Interior, Orflce of Education. Washingt on:U.S. Government Printing Office, 1935. 
UNPUBLISHED MATER IAL

Brand, Philip. A Comparative study of the Treatment of the Causes of the World War in Secondary School Textbooks of England, Germany, neutral powers, and the United States. New York: College of the CIty of New York, I935. (Unpubilshed Master's Thesis.)

Gargle, Irma N. A Comparative Study of the Treatment of the War of 1812 in English and American secondary school history textbooks. New York: College of the City of New York,1933. (Unpublished Master's Thesis.)

Palewsky, Isidore. A Comparative Study of the Treatment of the American Revolution and its causes in the history textbooks of the elementary schools of England and the United states. New York: College of the City of New York, 1931. (Unpublished Master's Thesis.) 


\section{EDUCATION}

Elementary-a--Public Schools of Louisville, Kentucky Secondary-----Louisville Girls' High School, Loulsville, Ky. College---n-A.A. University of Loulsville--1912 Graduate Work--M.A. University of Louisville--1937 Correspondence work with the University of Indiana and the University of Kentucky. Extension work with the University of Kentucky

Sumer work at the University of Loulsville

TEACHING RECORD

Elementary Schools in Louisville, Kentucky:

George Rogers Clark

Columbian

J.B. Atkinson

Junior High Schools in Louisville, Kentucky:

Eastern

Monsarrat

Parkland

Louisville Junfor H1gh School Senior High Schools in Loulsville, Kentucky: Louisville Girls' High School J.M. Atherton High School for Girls 